\title{
Buchwald-Hartwig Reactions of Monohaloflavones
}

\author{
Krisztina Kónya, ${ }^{\text {[a] }}$ Dávid Pajtás, ${ }^{\text {[a] }}$ Attila Kiss-Szikszai, ${ }^{\text {[a] }}$ and Tamás Patonay*[a]
}

Keywords: Homogeneous catalysis / Cross-coupling / Amination / Palladium / Amino acids / Oxygen heterocycles

The article describes the amination of different monobromoor monochloroflavones with primary and secondary alkylamines and aniline derivatives by Buchwald-Hartwig reaction. The influence of the phosphine ligands used is de- scribed. The use of amino acid derivatives as a nitrogen source is also demonstrated. This latter reaction allows the synthesis of unique flavone-amino-acid conjugates.

\section{Introduction}

Benzopyran derivatives with amino functionalities are a very important class of oxygen-containing heterocycles, and many of them have remarkable biological activity. Chromone and flavone alkaloids without a direct link between the aromatic/heteoaromatic ring and the amine nitrogen are natural products, and their occurrence and chemistry have been reviewed. ${ }^{[1]}$ Rohitukine, a chromone alkaloid isolated from Disoxylum binectifarum and Amoora rohituka, inhibits cyclin-dependent kinase (CDK). ${ }^{[2]}$ Its semisynthetic analogue, flavopiridol (Alvocidib, HMR 1275, L86-8275, NSC 649890) is an antineoplastic agent, inhibiting CDK1, CDK2, CDK4, CDK5, CDK6, and CDK9 kinases; it has been studied alone and in combinations in phase I and II clinical trials (Scheme 1). ${ }^{[3]}$

The other important subclass of amine-containing benzopyran derivatives consists of chromones and flavones in which the nitrogen is directly attached to an aromatic $\mathrm{sp}^{2}$ carbon. 7-Aminoflavone was found to show antibacterial effects against, among others, $M$. tuberculosis strains. ${ }^{[4,5]} 6$ Amino-5,7-dihydroxyflavone showed outstanding activity in the low micromolar range as an $\alpha$-glucosidase inhibitor. ${ }^{[6]}$

Many aminoflavones belonging to this second subclass have shown considerable cytotoxic, kinase inhibitory, or antiproliferative effects. 4'-Aminoflavones with one or more hydroxy groups in their A-ring have shown tyrosine-kinase inhibitory effect against p56 lck an enzyme of $56 \mathrm{kDa}$. The most active derivative was $4^{\prime}$-amino-6-hydroxyflavone. ${ }^{[7 a]}$ 5,7,4'-Triamino-6-hydroxyflavone selectively inhibited p56 lck, while 6,4'-diamino-7-hydroxyflavone and 5,7,3'-triamino-6-hydroxyflavone were more or less active against EGFr and p60 ${ }^{v-s r c}$. ${ }^{7 b]}$ 5,4'-Diaminoflavone, 5-amino-4'-dimethylaminoflavone, and 6-amino-4'-(dimethylamino)flav-

[a] Department of Organic Chemistry, University of Debrecen, 4032 Debrecen, Egyetem tér 1, Hungary E-mail: patonay.tamas@science.unideb.hu http://szerves.scienc.unideb.hu

$\square$ Supporting information for this article is available on the WWW under http://dx.doi.org/10.1002/ejoc.201403108. one have shown considerable antiproliferative effects against the MCF-7 breast-cancer cell line. ${ }^{[8]} 4^{\prime}$-Amino-6- or 7-fluoroisoflavones showed moderate antitumor effects against MDA-MB-468, MCF-7, HT29, and HCT-116 cell lines. $^{[9]}$ The aminoflavone-based peptide NSC 710464 (AFP 464) ${ }^{[10]}$ is considered to be an anticancer prodrug. It is in phase I clinical trials, and it seems to be useful against solid tumors (Scheme 1). ${ }^{[11]}$

3-Amino-4'-methoxyflavone and 3,3'-diamino-4' - methoxyflavone showed remarkable cytotoxicity aginst L1210 leukemia cells, and their 3-(diethylaminoethyl)amino analogues showed activities similar to those of the parent 3aminoflavones. $^{[12]}$ T-614, a 3-formamidochromone derivative, showed anti-inflammatory, antiarthritic, and oral antirheumatic effects. ${ }^{[13]} 3$-( $N^{\prime}$-Alkylureido)chromone and 3$\left(N^{\prime}\right.$-alkylureido)-1-thiochromone selectively inhibited the $\mathrm{v}-a b l$ tyrosine kinase. ${ }^{[14]}$

However, methods for the synthesis of aminochromones and flavones suffer from limitations, particularly for those derivatives with amine substituents in the A-ring. The most common synthetic methods are based on a ClaisenSchmidt condensation or a Baker-Venkataraman rearrangement (Scheme 2). In the first case, a base-induced aldol-type condensation gives a chalcone $\mathbf{2}$, which, in turn, can be cyclised into a nitro- or acetamidoflavone 3 . $^{[15-21]}$ The same intermediates (i.e., 3) are accessible by aroylation followed by Baker-Venkataraman rearrangement under strongly basic conditions. ${ }^{[7 b, 8,22-27]}$ The desired aminoflavones (i.e., 4) can be obtained by reduction or hydrolysis. The latter transformation usually requires harsh conditions (Scheme 2). The major problem with these methods is the synthesis of the appropriate acetophenone (i.e., 1), which is limited by the regioselectivity of the nitration of acetophenone, and by the sensitivity of the $\mathrm{R}^{1}$ substituents under the harsh conditions.

Alternatively, a previously constructed flavone moiety can also be nitrated and then submitted to reduction, but the reactivity and selectivity patterns of the nitration step are also limiting factors. ${ }^{[7 b, 28,29]}$ The Wessely-Moser re- 
<smiles>Cc1cc(=O)c2c(O)cc(O)c(C3CCN(C)CC3O)c2o1</smiles>

rohitukin<smiles>CN1CCC(c2c(O)cc(O)c3c(=O)cc(-c4ccccc4Cl)oc23)C(O)C1</smiles>

flavopiridol<smiles>COCCCC(N)C(=O)Nc1ccc(-c2cc(=O)c3c(N)c(F)c(C)c(F)c3o2)cc1F</smiles>

NSC710464 (AFP 464)<smiles>CS(=O)(=O)Nc1cc2occ(NC=O)c(=O)c2cc1O</smiles>

T-614<smiles>Cc1cc(N2C(=O)CN(C)C2=O)c2oc(-c3ccc(O)c(O)c3)c(O)c(=O)c2c1</smiles><smiles>[X]c1ccc(-c2oc3c(N4CCCS4(=O)=O)cc(C)cc3c(=O)c2O)cc1O</smiles>

Scheme 1.<smiles>[X]c1ccc([R])c(C(C)=O)c1O</smiles>

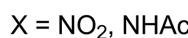<smiles>[3H][I+]=C</smiles><smiles>[R]c1ccc([X])c(C(=O)CC(=O)[Al])c1O</smiles>

5

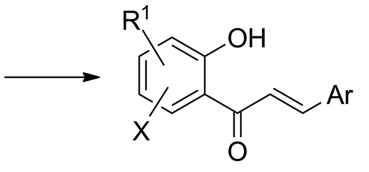

2<smiles>[X]c1cc2oc(Br)cc(=O)c2cc1[R]</smiles><smiles>[R]c1ccc2c(=O)cc([Al])oc2c1</smiles>

6<smiles>[R]c1cc(N)c2c(=O)cc(Br)oc2c1</smiles>

4

Scheme 2.

arrangement is a special route to aminoflavones. ${ }^{[6,28,30]}$ The synthesis of alkyl/arylamino or disubstituted amino derivatives represents a much greater challenge. Direct alkylation suffers from a lack of selectivity, which leads to low yields. $^{[8,15]}$ Alkylation of an acetamido or sulfonylamido group followed by the cleavage of the protecting group has been reported. ${ }^{[9,28]}$ Reductive alkylation, ${ }^{[31,32]}$ and direct aromatic nucleophilic substitution of an aromatic triflyloxy group under microwave conditions ${ }^{[33]}$ have also been described.

The synthesis of 3-aminoflavones 7 can be carried out by the reduction of 3-nitro $\mathbf{8}^{[12,16,34-37]}$ or 3-oximino derivatives 9, or from 3-azidoflavanones $\mathbf{1 0}$ under basic conditions. ${ }^{[38-40]}$ Reduction of the nitro group has been carried out by catalytic hydrogenation. ${ }^{[12,34,41,42]} 3$-Oximinoflavanones 9 gave also 3-aminoflavones 7 upon treatment with tin(II) chloride (Scheme 3). ${ }^{[43,44]}$<smiles>[R][R]1cccc2c1OC([Al])C(N)C2=O</smiles>

Scheme 3.

Sasaki, Miyake, and their coworkers published the synthesis of various 3-alkylaminoflavones from 3-bromoflavones, ${ }^{[45 a]} 3$-tosyloxyflavones, or 3-mesyloxyflavones, ${ }^{[45 b]}$ but 
the structural assignment of their products proved to be wrong (vide infra).

In recent decades, Buchwald-Hartwig amination of halosubstituted aromatic/heteroaromatic systems has become the method of choice for the synthesis of alkyl- and arylamino substituted arenes. ${ }^{[46]}$ Surprisingly, only sporadic examples have been published in the field of oxygen heterocycles. There are only two published examples of the preparation of amino derivatives: the synthesis of 7-amino-5hydroxyflavone started from a triflate, ${ }^{[47]}$ while 4 '-aminoisoflavone was prepared from the corresponding bromide. ${ }^{[12]}$ Caddick and his coworkers reported the Buchwald-Hartwig reaction of bromo- or triflyloxy-substituted flavones under microwave activation, but they only used hexylamine as the nitrogen source. ${ }^{[48]}$ This astonishing gap in the amination of oxygen heterocycles prompted us to start a systematic investigation of the scope and limitations of this method. We present our first results in this paper.

\section{Results and Discussion}

We started our studies using the conditions of Caddick's group ${ }^{[48]}$ but a much wider variety of primary and secondary aliphatic and aromatic amines were tested. It turned out that microwave activation has no beneficial effect; reactions using conventional thermal heating show the same efficiency. Reactions of 6-bromoflavone (11) with various amines in the presence of $\operatorname{Pd}_{2}(\mathrm{dba})_{3}(\mathrm{dba}=$ dibenzylideneacetone) as a palladium source resulted in the formation of the desired 6-aminoflavones (i.e., 12a-12p; Scheme 4, Table 1). The only limiting factor is steric hindrance in the reacting amine. Increasing the number of $\alpha$-branchings clearly decreases the yield (Table 1 , entries $1-4$ ). A similar effect was also observed in the reactions of 7-bromoflavone (17; vide infra). The lower yield for the reaction with dibutylamine in comparison with the cyclic secondary amines (Table 1, entry 10 vs. entries 11-14) also supports the role of bulkiness.
Table 1. Amination of 6-bromoflavone (11).

\begin{tabular}{|c|c|c|c|c|}
\hline Entry & Product & $\mathrm{R}^{1}$ & $\mathrm{R}^{2}$ & Yield $[\%]^{[\mathrm{a}]}$ \\
\hline 1 & $12 \mathrm{a}$ & $\mathrm{Bu}$ & $\mathrm{H}$ & $46^{[\mathrm{b}]}$ \\
\hline 2 & $12 \mathrm{~b}$ & $i \mathrm{Bu}$ & $\mathrm{H}$ & 46 \\
\hline 3 & $12 \mathrm{c}$ & $s \mathrm{Bu}$ & $\mathrm{H}$ & 38 \\
\hline 4 & 12d & $t \mathrm{Bu}$ & $\mathrm{H}$ & $0^{[\mathrm{c}, \mathrm{d}]}$ \\
\hline 5 & $12 \mathrm{e}$ & $\mathrm{Bn}$ & $\mathrm{H}$ & 59 \\
\hline 6 & $12 f$ & $c$ Hex & $\mathrm{H}$ & 57 \\
\hline 7 & $12 \mathrm{~g}$ & $2-\mathrm{Me}-\mathrm{C}_{6} \mathrm{H}_{4}$ & $\mathrm{H}$ & 53 \\
\hline 8 & $12 \mathrm{~h}$ & $4-\mathrm{Cl}-\mathrm{C}_{6} \mathrm{H}_{4}$ & $\mathrm{H}$ & 48 \\
\hline 9 & $12 \mathrm{i}$ & $4-\mathrm{MeO}-\mathrm{C}_{6} \mathrm{H}_{4}$ & $\mathrm{H}$ & 75 \\
\hline 10 & $12 \mathrm{j}$ & $\mathrm{Bu}$ & $\mathrm{Bu}$ & 18 \\
\hline 11 & $12 \mathrm{k}$ & \multicolumn{2}{|c|}{$-\left(\mathrm{CH}_{2}\right)_{4}-$} & 40 \\
\hline 12 & 121 & \multicolumn{2}{|c|}{$-\left(\mathrm{CH}_{2}\right)_{5^{-}}$} & 58 \\
\hline 13 & $12 \mathrm{~m}$ & \multicolumn{2}{|c|}{$-\left(\mathrm{CH}_{2}\right)_{2} \mathrm{O}\left(\mathrm{CH}_{2}\right)_{2}-$} & 51 \\
\hline 14 & $12 n$ & \multicolumn{2}{|c|}{$-\left(\mathrm{CH}_{2}\right)_{2} \mathrm{Me}\left(\mathrm{CH}_{2}\right)_{2-}$} & 73 \\
\hline 15 & 120 & $\mathrm{Ph}$ & $\mathrm{Me}$ & 31 \\
\hline 16 & $12 p$ & 1,2,3,4-tetrahy & uinolin-1-yl & 48 \\
\hline
\end{tabular}

[a] Yields refer to pure isolated products. [b] $N, N$-Bis(flavon-6-yl)butylamine $(14 ; 11 \%)$ was also isolated. [c] Traces of the expected product could be detected by TLC. [d] Flavone $(13 ; 7.7 \%)$ and $\beta$ diketone $15(15 \%)$ were isolated. These by-products were also detected by TLC in several other reactions.

In all cases, flavone (13) was detected or isolated as a byproduct. Competitive reductive elimination and $\beta$-hydride elimination from the organopalladium intermediate may both take place to reform the catalyst, but the latter pathway gives a dehalogenated product, i.e., flavone (13), which results in a decrease of the yield of the aminated product. In the reaction of substrate $\mathbf{1 1}$ with butylamine, an interesting bis-arylated product $\mathbf{1 4}$ was also obtained in low (11\%) yield. Obviously, here the Buchwald-Hartwig product acts as the amine in a second cross-coupling reaction. Surprisingly, no similar double Buchwald-Hartwig coupling was observed with any of the other amines tested. It is noteworthy that Caddick and his coworkers ${ }^{[48]}$ also mentioned the formation of a similar diflavonoid tertiary amine derivative starting from 4 '-bromo-2' -chloro-6-methylflavone and hexylamine. In some cases, we also observed the formation of 5'-bromo-2'-hydroxydibenzoylmethane (and its tautomeric form) (15). The appearance of this by-product under the strictly water-free conditions used can be explained by

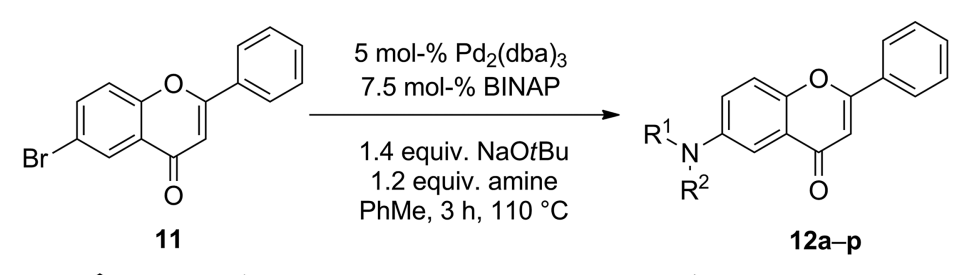<smiles>O=c1cc(-c2ccccc2)oc2ccccc12</smiles><smiles>O=C(c1ccccc1)N(c1ccc2oc(-c3ccccc3)cc(=O)c2c1)c1ccc2oc(-c3ccccc3)cc(=O)c2c1</smiles><smiles>O=C(/C=C(\O)c1cc(Br)ccc1O)c1ccccc1</smiles>

Scheme 4. 


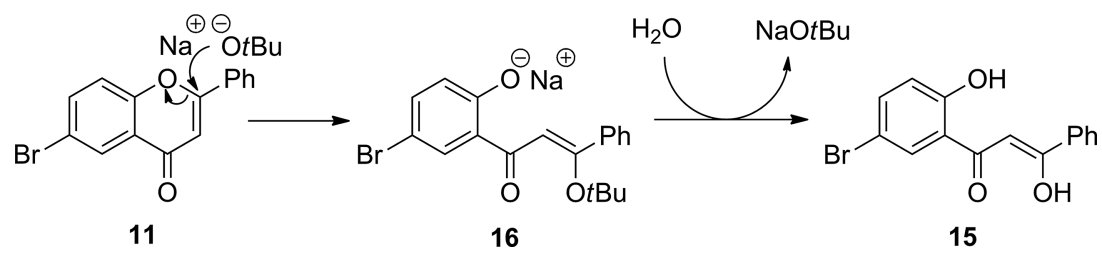

Scheme 5 .<smiles>C1CCC(P(C2CCCCC2)C2CCCCC2)CC1</smiles>

A

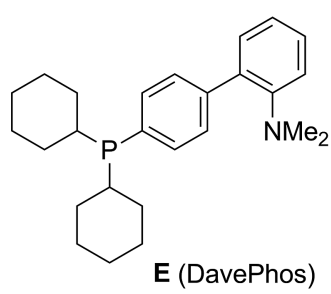

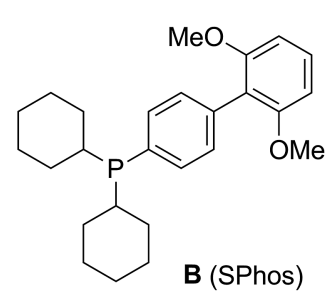

B (SPhos)

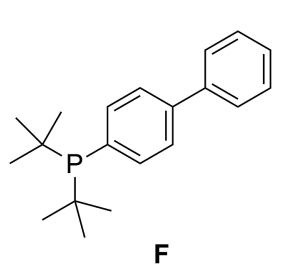<smiles>CC(C)c1cc(C(C)C)c(-c2ccc(P(C3CCCCC3)C3CCCCC3)cc2)c(C(C)C)c1</smiles><smiles>c1ccc(-c2ccc(P(C3CCCCC3)C3CCCCC3)cc2)cc1</smiles><smiles>Pc1ccccc1-c1ccc2ccccc2c1-c1c(P)ccc2ccccc12</smiles>

I (BINAP)<smiles>CC(C)c1cc(C(C)C)c(-c2ccc(P(C(C)(C)C)C(C)(C)C)cc2)c(C(C)C)c1</smiles>

D<smiles>CCCCCc1cccc2c1Oc1c(P)cccc1C2(C)C</smiles>

H (Xantphos)

Scheme 6. Structures of the ligands used.

a concurrent ring-opening of the heterocycle: the tertbutoxide anion attacks the electrophilic C-2 atom of the flavone moiety, and the intermediate enol ether (i.e., 16) hydrolyses during aqueous work-up and column chromatography on silica (Scheme 5).

Next, we investigated the role of the phosphine ligands and their effect on the yield of the cross-coupling reaction. 6-Bromoflavone (11) was treated with butylamine, cyclohexylamine, or piperidine in the presence of various phosphines A-I (Scheme 6) keeping all the other reagents the same, but using microwave activation. The amount of the 6-(di)substituted aminoflavone product (i.e., 12a, 12f, or 12I) was determined by HPLC. The results are summarised in Table 2, and they clearly show that there is no "magic" ligand with outstanding efficiency for every model amine. The best yields were achieved using electron-rich monodentate biaryl ligands, particularly ligands $\mathbf{B}, \mathbf{C}$, and $\mathbf{E}$.

The average HPLC yields were $>45 \%$, but there were large deviations. For example, ligand I gave good results with primary amines, but only a low HPLC yield with the secondary amine piperidine. We can conclude that many of these ligands can be used successfully, but a detailed optimisation is needed in each case.

We chose 7-bromoflavone (17) as our next substrate to allow a comparison of the reactivity of the 6- and 7-positions. We have previously demonstrated the higher reactivity of the 7-position in Heck-Mizoroki reactions. ${ }^{[49]}$ Bromide 17 was treated with various amines under the same conditions as described above (Scheme 7, Table 3). The reactions were successful with all the tested acyclic and cyclic aliphatic amines as well as aniline derivatives, and the yields
Table 2. Efficiency of the amination of 6-bromoflavone (11) in the presence of different phosphine ligands. ${ }^{[a]}$

\begin{tabular}{lccc}
\hline Ligand & $\mathrm{BuNH}_{2}$ & $\begin{array}{c}\text { HPLC area }[\%]^{[\mathrm{b}]} \\
c \text { HexNH }_{2}\end{array}$ & Piperidine \\
\hline $\mathbf{A}$ & 1 & 3 & 15 \\
$\mathbf{B}$ & 45 & 51 & 79 \\
$\mathbf{C}$ & 43 & 35 & 61 \\
$\mathbf{D}$ & 28 & 15 & 6 \\
$\mathbf{E}$ & 41 & 43 & 60 \\
$\mathbf{F}$ & 29 & 30 & 28 \\
$\mathbf{G}$ & 31 & 29 & 55 \\
$\mathbf{H}$ & 38 & 27 & 57 \\
I & 75 & 43 & 24
\end{tabular}

[a] Reaction conditions: $\operatorname{Pd}_{2}(\mathrm{dba})_{3}(5 \mathrm{~mol}-\%)$, ligand $(7.5 \mathrm{~mol}-\%)$, $\mathrm{NaO} t \mathrm{Bu}$ (1.4 equiv.), amine (1.2 equiv.), dry toluene, $\mathrm{MW}\left(110^{\circ} \mathrm{C}\right)$, 15 min. [b] Product ratios were determined by HPLC; Pinnacle II $\mathrm{C} 18$ column, $150 \times 4.6 \mathrm{~mm}, \mathrm{MeOH} / \mathrm{H}_{2} \mathrm{O}$ (gradient).

were either similar to or better than those obtained with 6bromoflavone (11). This observation was consistent with our expectations: the electronic effect of a carbonyl group in the para position usually speeds up palladium-catalysed cross-coupling reactions. We can assume that the rate-de-

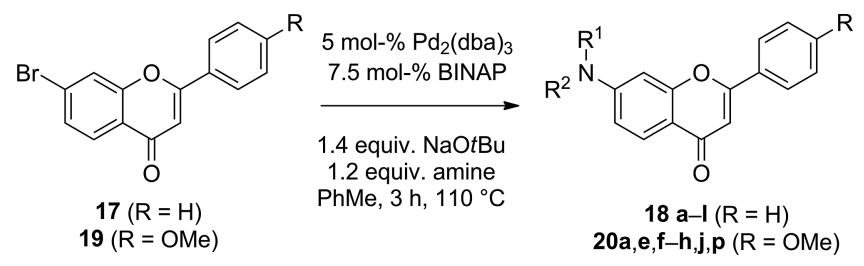

Scheme 7. 
termining step of this amination is the oxidative addition, i.e., the insertion of palladium $(0)$ into the $\mathrm{C}-\mathrm{Br}$ bond.

Table 3. Amination of 7-bromoflavone (17).

\begin{tabular}{lclcc}
\hline Entry & Product & $\mathrm{R}^{1}$ & $\mathrm{R}^{2}$ & Yield [\%] ${ }^{[\mathrm{a}]}$ \\
\hline 1 & $\mathbf{1 8 a}$ & $\mathrm{Bu}$ & $\mathrm{H}$ & 81 \\
2 & $\mathbf{1 8 b}$ & $i \mathrm{Bu}$ & $\mathrm{H}$ & 79 \\
3 & $\mathbf{1 8 c}$ & $s \mathrm{Bu}$ & $\mathrm{H}$ & 79 \\
4 & $\mathbf{1 8 d}$ & $t \mathrm{Bu}$ & $\mathrm{H}$ & 28 \\
5 & $\mathbf{1 8 e}$ & $\mathrm{Bn}$ & $\mathrm{H}$ & 89 \\
6 & $\mathbf{1 8 f}$ & $4-\mathrm{Cl}-\mathrm{C}_{6} \mathrm{H}_{4}$ & $\mathrm{H}$ & 55 \\
7 & $\mathbf{1 8 g}$ & $4-\mathrm{MeO}-\mathrm{C}_{6} \mathrm{H}_{4}$ & $\mathrm{H}$ & 74 \\
8 & $\mathbf{1 8 h}$ & $\mathrm{Bu}$ & $\mathrm{Bu}$ & 16 \\
9 & $\mathbf{1 8 i}$ & \multicolumn{2}{c}{$-\left(\mathrm{CH}_{2}\right)_{4}-$} & 79 \\
10 & $\mathbf{1 8 j}$ & \multicolumn{2}{c}{$-\left(\mathrm{CH}_{2}\right)_{5}^{-}$} & 55 \\
11 & $\mathbf{1 8 k}$ & \multicolumn{2}{c}{$-\left(\mathrm{CH}_{2}\right)_{2} \mathrm{O}\left(\mathrm{CH}_{2}\right)_{2}-$} & 74 \\
12 & $\mathbf{1 8 l}$ & $\mathrm{Ph}$ & $\mathrm{Me}$ & 41 \\
\hline
\end{tabular}

[a] Yields refer to pure isolated products.

We also compared the reactions of 6- and 7-haloflavones containing different halogen atoms under our standard conditions. Consistent with our expectations, bromoflavones 11 and 17 gave much higher yields than the corresponding 6chloro (21) and 7-chloro (22) derivatives (Table 4). This difference can be explained on the basis of the higher activation energy of the oxidative addition step of the shorter and stronger $\mathrm{C}-\mathrm{Cl}$ bond, and the electronic effect of the carbonyl group in the para position.

Table 4. Isolated yields from the Buchwald-Hartwig reactions of 6/7-bromo- and -chloroflavones 11, 17, 21, and 22 with various amines.

\begin{tabular}{lcccc}
\hline Amine & \multicolumn{4}{c}{${\text { Yield }[\%]^{[\mathrm{a}]}}$} \\
\hline $\mathrm{BuNH}_{2}$ & 46 & 81 & 7.7 & 32 \\
$\mathrm{BnNH}_{2}$ & 59 & 89 & 8.8 & 41 \\
Pyrrolidine & 40 & 79 & 7.3 & 38 \\
4-Cl- $\mathrm{C}_{6} \mathrm{H}_{4}$ & 48 & 55 & 6.5 & 36 \\
\hline
\end{tabular}

[a] Yields refer to pure isolated products.

Next, we tested the amination of 7-bromo-4'-methoxyflavone (19) with some model primary and secondary amines (Scheme 7). No significant differences could be observed in the yields of the coupled products. The distant substituent does not exert any significant electronic effect (see Supporting Information).

Next, we studied the possible Buchwald-Hartwig reaction of 3-bromoflavone (23) under our previously optimised conditions, since the number of methods that have been reported for the preparation of 3-alkyl/arylaminoflavones or related systems is very limited (vide supra). Unfortunately, this coupling reaction gave the expected amines (i.e., 24) in much lower yields than those obtained with the bromides studied earlier (i.e., 11, 17, and 19), particularly with secondary amines (Scheme 8, Table 5). The use of microwave activation did not change the outcome of the coupling reactions (Table 5, entry 2). Typically, reductive elimination leading to flavone (13) took place to a considerable extent.
We can conclude that this method, although it seems to work, has only limited synthetic value for the preparation of mono- or alkylated/arylated 3-aminoflavone derivatives.
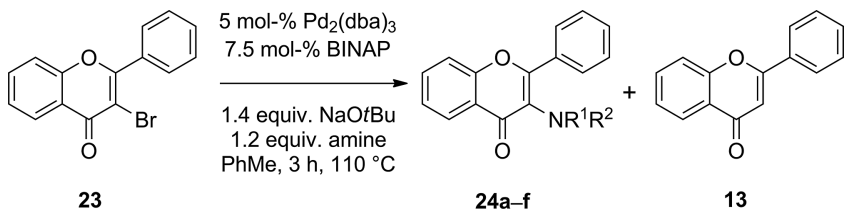

Scheme 8 .

Table 5. Synthesis of 3-aminoflavone derivatives $\mathbf{2 4}$ by BuchwaldHartwig reaction.

\begin{tabular}{lclccc}
\hline Entry & Product & $\mathrm{R}^{1}$ & $\mathrm{R}^{2}$ & Yield $[\%]^{[\mathrm{a}]}$ & Yield of $\mathbf{1 3}[\%]^{[\mathrm{a}]}$ \\
\hline 1 & $\mathbf{2 4 a}$ & $\mathrm{Bu}$ & $\mathrm{H}$ & 33 & 14 \\
$2^{[\mathrm{b}]}$ & $\mathbf{2 4 a}$ & $\mathrm{Bu}$ & $\mathrm{H}$ & 27 & n.d. \\
3 & $\mathbf{2 4 b}$ & $\mathrm{Hex}$ & $\mathrm{H}$ & 23 & n.d. \\
4 & $\mathbf{2 4 c}$ & $\mathrm{Bn}$ & $\mathrm{H}$ & 56 & 9 \\
5 & $\mathbf{2 4 d}$ & \multicolumn{2}{c}{$-\left(\mathrm{CH}_{2}\right)_{4}-$} & 13 & 17 \\
6 & $\mathbf{2 4 e}$ & \multicolumn{2}{c}{$-\left(\mathrm{CH}_{2}\right)_{5}$} & 6 & 26 \\
7 & $\mathbf{2 4 f}$ & $4-\mathrm{Me}-\mathrm{C}_{6} \mathrm{H}_{4}$ & $\mathrm{H}$ & 26 & n.d. \\
\hline
\end{tabular}

[a] Yields refer to pure isolated products; n.d.: not determined. [b] Reaction carried out under $\mathrm{MW}$ irradiation $\left(110^{\circ} \mathrm{C}, 15 \mathrm{~min}\right.$, $200 \mathrm{~W})$.

Earlier both Caddick's group ${ }^{[48]}$ and Miyake's group ${ }^{[45]}$ reported the synthesis of 3-alkylaminoflavones from 3bromo-, 3-tosyloxy-, or 3-mesyloxyflavones. Caddick and his coworkers ${ }^{[51]}$ treated 3-bromoflavone (23) with hexylamine under microwave irradiation, but in the presence of $\mathrm{Pd}(\mathrm{OAc})_{2}$ instead of $\mathrm{Pd}_{2}(\mathrm{dba})_{3}$ used previously. However, our ${ }^{1} \mathrm{H}$ and ${ }^{13} \mathrm{C}$ NMR spectroscopic data were completely different from those reported by them in their Supplementary Information. The major problem with the assignment of the right structure is that the heterocyclic product contains only quaternary carbons, which makes the ring size questionable. Miyake and his coworkers also reported the synthesis of 3-amino- or 3-(alkylamino)flavones in good or excellent yields by simply treating 3-bromo-, 3-(tosyloxy)-, or 3-(mesyloxy)flavones with ammonia or with primary amines in THF solution at room temperature, but they did not present any m.p. values or spectroscopic data. ${ }^{[45]}$ Therefore, we tested their reaction conditions by treating 3bromoflavone (23) with butylamine and hexylamine in THF without any palladium source. The isolated products had identical or similar spectral data to "3-hexylaminoflavone" reported by Caddick et al. The spectral data indicated the presence of the same groups, thus, our Buchwald-Hartwig products and the Caddick/Miyake products should be structural isomers; one of them is the expected 3-(alkylamino)flavone, while the other is 2-[ $\alpha$-(alkylamino)benzylidene]benzofuran-3(2H)-one, a product of a ring-contraction. Significant differences could be found between the ${ }^{1} \mathrm{H}$ NMR data of our Caddick/Miyake products and our Buchwald-Hartwig products. The Caddick/Miyake products showed NH signals at $\delta=10 \mathrm{ppm}$, signals of the hydrogen in the peri position to the carbonyl group at $\delta=7.84 \mathrm{ppm}$, and $\mathrm{NCH}_{2}$ signals at $\delta \approx 3.22 \mathrm{ppm}$. The corresponding values for our Buchwald-Hartwig products were $\delta \approx 4.4$, 


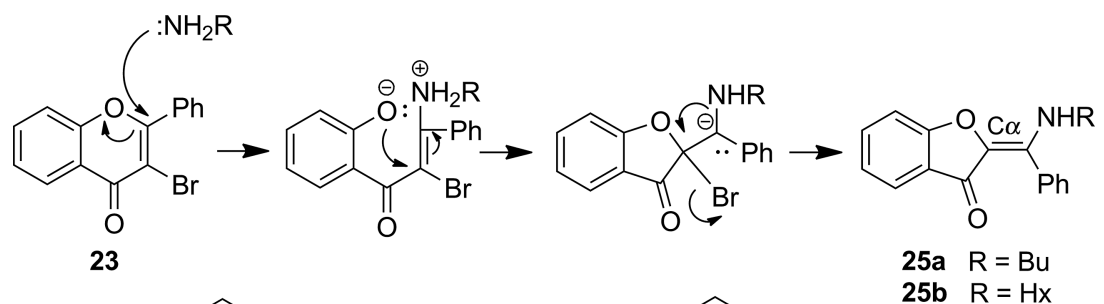<smiles>Nc1c(-c2ccccc2)oc2ccccc2c1=O</smiles>

26

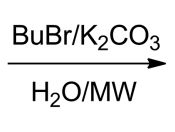<smiles>Nc1c(-c2ccccc2)oc2ccccc2c1=O</smiles>

25b $\quad \mathrm{R}=\mathrm{Hx}$

Scheme 9.

8.25, and $2.64 \mathrm{ppm}$, respectively. The ${ }^{13} \mathrm{C}$ NMR signals differed less markedly. We carried out 2D NMR spectroscopic measurements (COSY and HMBC) for both of the butylsubstituted compounds to assign the signals of the carbon and hydrogen atoms (see Supporting Information). HMBC measurements showed a strong cross-peak between the $1^{\prime \prime}$ $\mathrm{H}\left(\mathrm{NCH}_{2}\right)$ and $\mathrm{C}_{\alpha}$ signals in the spectrum of the Caddick/ Miyake product. On the other hand, the cross-peak between the 1"'-H $\left(\mathrm{NCH}_{2}\right)$ and $\mathrm{C}-3$ signals in our BuchwaldHartwig product clearly proved that Caddick/Miyake product should be 2-[ $\alpha$-(butylamino)benzylidene]benzofuran$3(2 H)$-one (25a).

The formation of the ring-contracted products (i.e., 25a and 25b) can be explained in terms of attack of the amine nucleophile on the $\mathrm{C}-2$ atom of the oxygen heterocycle (Scheme 9).

To obtain additional and independent proof for the structure of 3-(butylamino)flavone (24a) obtained in the Buchwald-Hartwig procedure, and to rule out isomeric structure 25a, we alkylated the parent 3-aminoflavone (i.e., 26) with butyl bromide in aqueous solution in the presence of potassium carbonate under microwave irradiation using the protocol developed for 3 -( $N, N$-alkylamino)flavones. ${ }^{[50]}$ The resulting product showed the same spectroscopic data as our Buchwald-Hartwig product, thus proving that the structures of Caddick's and Miyake's compounds were erroneously assigned.

We also investigated the synthesis of $N$-unsubstituted aminoflavones. The most frequently used ammonia equivalents in Buchwald-Hartwig cross-coupling are benzophenone imine ${ }^{[51]}$ and lithium silyl amides. ${ }^{[52]}$ Until now, only one example has been published in the field of flavones. ${ }^{[47]}$ We successfully prepared both 6-aminoflavone (28a) and 7aminoflavone (28b) via the corresponding imine intermediates (i.e., 27a and 27b) in 48 and $38 \%$ overall yields, respectively (Scheme 10). Unfortunately, the reaction of 3-bromoflavone (23) failed to give the desired 3-aminoflavone (27).

Next, we tested the cross-coupling reaction with $\alpha$-amino acid methyl esters as the nitrogen source. This reaction could lead to hitherto almost unknown amino-acid-flavone hybrids of potential biological importance. To the best of our knowledge, only two examples of such derivatives have
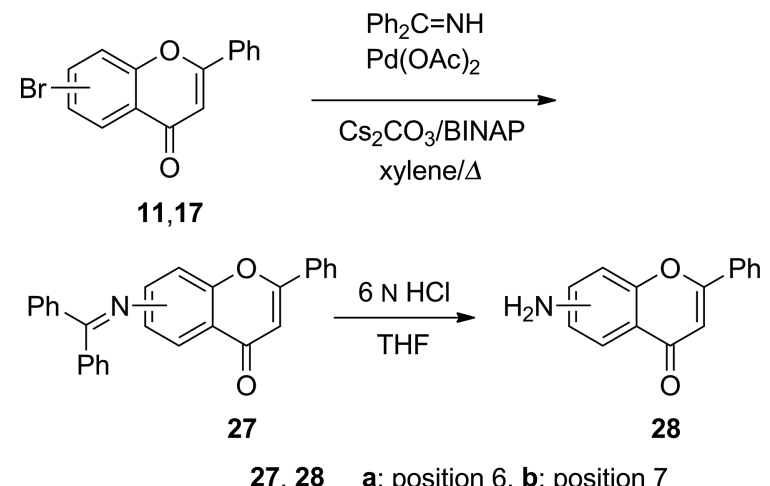

Scheme 10.

been published to date, and neither of them was obtained by Buchwald-Hartwig (or Ullmann) type coupling. Korean authors ${ }^{[53]}$ prepared a conjugate by alkylation of a preformed 6-aminoflavone (28a) with an $\alpha$-bromo- $\alpha$-phenylacetic acid thioester, while Georg et al. ${ }^{[54]}$ coupled 8amino-4'-chloro-5-hydroxyflavone with $N$-Boc-protected amino acids (Boc $=$ tert-butoxycarbonyl). First, we treated 6-bromoflavone (11) with L-phenylalanine methyl ester hydrochloride (29a), but the desired coupled product could not be obtained under the previously used conditions. After extensive optimisation, we found a set of conditions: $\mathrm{Pd}_{2}(\mathrm{dba})_{3}$ should be replaced by palladium(II) acetate, and the original base sodium tert-butoxide should be replaced by cesium carbonate. However, the expected product (i.e., 30a) was only obtained in a very low yield $(5 \%)$, and, in addition, the regioisomeric 7-\{[2-phenyl-1-(methoxycarbonyl)ethyl]amino\}flavone (31a) was also isolated in $6 \%$ yield (Scheme 11). These structures were assigned on the basis of their NMR spectra, and the constitution of compound 31a was also supported by its independent synthesis (vide infra).

A possible explanation for this astonishing observation may be the so-called "halogen dance"[55] under the strongly basic conditions. According to this suggested mechanism, a deprotonation at the 7-position of the starting 6-bromoflavone (11) takes place, followed by a bromine exchange between the resulting carbanion intermediate and a second 


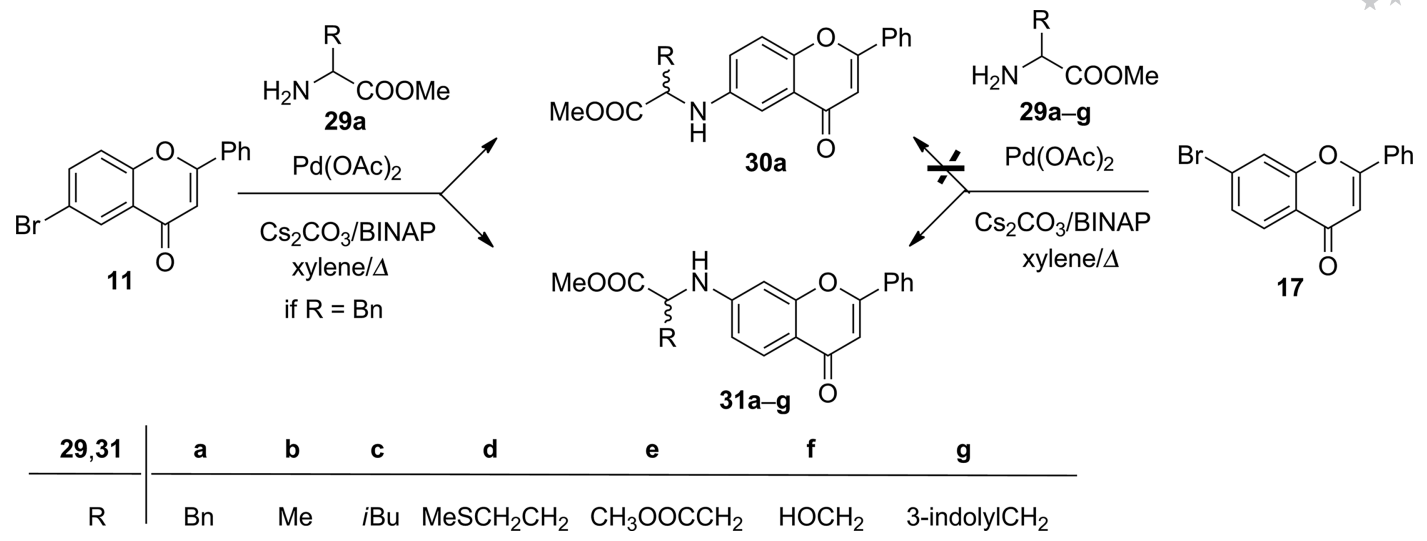

Scheme 11.

molecule of starting material to give 6,7-dibromoflavone. The relative ease of this deprotonation may be explained by the higher stability of this carbanion. The 6,7-dibromoflavone intermediate may react with the above-mentioned carbanion to yield 7-bromoflavone (17). These hypothetical steps are consistent with the generally accepted mechanism of the "halogen dance". However, it should be emphasised that the "halogen dance" usually needs more basic conditions [LDA (dithium diisopropylamide), $\mathrm{BuLi}, \mathrm{NaNH}_{2}$, ArNHK, etc.]. In addition, to the best of our knowledge, this would be the first example of such a transformation to be observed in a Buchwald-Hartwig reaction.

Applying the same conditions to the reaction of 7 bromoflavone (17) and various amino acid methyl ester hydrochlorides 29, the expected products (i.e., 31a-31e) were obtained (Scheme 11, Table 6), and no 6-substituted products were obtained or detected. The higher reactivity of 7-bromoflavone (17) caused by electronic effects (vide supra) leads to a fast reaction, and so excludes the "halogen dance". These results further demonstrate the synthetic utility of the Buchwald-Hartwig reaction in the field of oxygen heterocycles. On the other hand, the data summarised in Table 6 clearly show that the polarity of the amino acid has a decisive role in the efficiency of the reaction. The coupling with $\mathrm{L}$-aspartic acid resulted in a low yield, and no product was obtained with L-serine or L-tryptophan. The lack of any reaction may be explained by either the low solubility of the amino acid derivative in xylene, or by ligation of the palladium(0)/palladium(II) ion to the heteroatom of the reagent.

Table 6 . Synthesis of flavone-amino-acid hybrids $\mathbf{3 1}$ by BuchwaldHartwig reaction.

\begin{tabular}{lcccc}
\hline Entry & Amino acid & Product & Yield [\%] & ee [\%] \\
\hline 1 & L-Phe & 31a & 64 & 6 \\
2 & D-Phe & 31a & 59 & 10 \\
3 & L-Ala & 31b & 30 & n.d. \\
4 & L-Leu & 31c & 56 & 6 \\
5 & L-Met & 31d & 40 & 1 \\
6 & L-Asp & 31e & 11 & 2 \\
7 & L-Ser & 31f & 0 & - \\
8 & L-Trp & 31g & 0 & - \\
\hline
\end{tabular}

Another drawback of coupling with amino acid esters, at least at the moment, is racemisation (Table 6). This can be attributed to a deprotonation-reprotonation sequence at the stereogenic centre of the amino acid unit.

\section{Conclusions}

In conclusion, we have demonstrated that the BuchwaldHartwig amination of bromoflavones with halo substituents on their aromatic rings is a useful tool for the synthesis of amine derivatives that are hardly available by previously reported methods. We have pointed out that the previously published structures of some derivatives obtained from 3halo- or sulfonyloxyflavones with primary amines were erroneously assigned, and that in fact, ring-contracted products were formed. Palladium-catalysed $\mathrm{C}-\mathrm{N}$ bond formation also proved to be an efficient tool in the synthesis of flavone-amino-acid hybrids, although the coupling takes place accompanied by significant racemisation of the stereogenic centre. Experiments aimed at avoiding this racemisation and extending the number of nitrogen sources are in progress, and the results will be published soon.

\section{Experimental Section}

General Remarks: Column chromatography was carried out on silica gel (Merck 60, 70-230 mesh). Thin-layer chromatography was carried out on silica gel plates $60 \mathrm{~F}_{254}$ (Merck, $0.2 \mathrm{~mm}$ ). In phosphine-ligand optimisation studies, product ratios were determined by HPLC using a Pinnacle II column $(\mathrm{C} 18,150 \times 4.6 \mathrm{~mm}, 5 \mu \mathrm{m}$; $\mathrm{MeOH} / \mathrm{H}_{2} \mathrm{O}$, gradient: from 60 to $90 \% \mathrm{MeOH}$ in $20 \mathrm{~min}$; flow: $0.9 \mathrm{~mL} / \mathrm{min}, 280 \mathrm{~nm})$. Chiral HPLC was carried out using a Chiralpak IC column $(250 \times 4.6 \mathrm{~mm})$ with a Jasco HPLC system: Jasco PU-980 HPLC pump, Jasco MD-910 multiwavelength detector. The purity of the compounds was established by GC-MS (Agilent 7890, Agilent $5975 \mathrm{MS}$ detector) with positive EI at $70 \mathrm{eV}$. NMR spectra were recorded with a Bruker AM $360\left(360.13 \mathrm{MHz}\right.$ for ${ }^{1} \mathrm{H}$, $90.03 \mathrm{MHz}$ for ${ }^{13} \mathrm{C}$ ) spectrometer. Chemical shifts $(\delta)$ were calibrated using the $\mathrm{CHCl}_{3}$ signals $(\delta=7.26 \mathrm{ppm})$ for ${ }^{1} \mathrm{H}$ and $(\delta=$ 
$77.00 \mathrm{ppm}$ ) for ${ }^{13} \mathrm{C}$ spectra. Melting points were determined by using Büchi B-540 equipment. Elemental analysis $(\mathrm{C}, \mathrm{H})$ was conducted with an Elementar Vario MicroCube instrument. IR spectra were measured as $\mathrm{KBr}$ discs with a Jasco FTIR 4100A instrument. Microwave-assisted reactions were carried out using a CEM-Discover Focused microwave synthesis system $(2450 \mathrm{MHz})$.

6-Bromoflavone (11), ${ }^{[56]}$ 7-bromoflavone (17), ${ }^{[56]}$ and amino acid methyl ester hydrochlorides ${ }^{[57]}$ were synthesised according to literature procedures.

Buchwald-Hartwig Cross-Coupling by Thermal Heating: Haloflavone (0.66 mmol), $\mathrm{NaO} t \mathrm{Bu}(88 \mathrm{mg}, 0.92 \mathrm{mmol})$, BINAP [2,2'bis(diphenylphosphino)-1,1'-binaphthyl; $32 \mathrm{mg}, 0.050 \mathrm{mmol}]$, and amine $(0.80 \mathrm{mmol})$ were mixed in dry toluene $(6 \mathrm{~mL})$ in a dried flask under nitrogen, and $\mathrm{Pd}_{2}(\mathrm{dba})_{3}(30 \mathrm{mg}, 0.032 \mathrm{mmol})$ was added. The reaction mixture was stirred at reflux for $3 \mathrm{~h}$ in an oil bath. The crude reaction mixture was applied directly to a silica gel column to give the pure cross-coupled product.

Buchwald-Hartwig Cross-Coupling by Microwave Activation: 6Bromoflavone $(0.33 \mathrm{mmol}), \mathrm{NaO} t \mathrm{Bu}(44 \mathrm{mg}, 0.46 \mathrm{mmol})$, BINAP $(15 \mathrm{mg}, 0.025 \mathrm{mmol})$, and amine $(0.80 \mathrm{mmol})$ were mixed in dry toluene $(3 \mathrm{~mL})$ in a sealed vial under nitrogen, and $\operatorname{Pd}_{2}(\mathrm{dba})_{3}$ $(15 \mathrm{mg}, 0.016 \mathrm{mmol})$ was added. The reaction mixture was stirred for $15 \mathrm{~min}$ at $110{ }^{\circ} \mathrm{C}(200 \mathrm{~W})$. The crude reaction mixture was applied directly to a silica gel column to give the pure cross-coupled product.

Only representative examples are given here. Characterisation data for the vast majority of the products are presented in the Supporting Information.

6-(Butylamino)flavone (12a): Eluent: toluene/ethyl acetate, 4:1; yield $88 \mathrm{mg}(46 \%)$ from 11, $15 \mathrm{mg}(7.7 \%)$ from 21; m.p. $124.5-126.5^{\circ} \mathrm{C}$. ${ }^{1} \mathrm{H}$ NMR $\left(\mathrm{CDCl}_{3}\right): \delta=7.89\left(\mathrm{~m}, 2 \mathrm{H}, 2^{\prime}-\mathrm{H}, 6^{\prime}-\mathrm{H}\right), 7.50(\mathrm{~m}, 3 \mathrm{H}$, $\left.3^{\prime}-\mathrm{H}, 5^{\prime}-\mathrm{H}, 4^{\prime}-\mathrm{H}\right), 7.39$ (d, $\left.J=8.6 \mathrm{~Hz}, 1 \mathrm{H}, 8-\mathrm{H}\right), 7.24$ (d, $J=$ $2.5 \mathrm{~Hz}, 1 \mathrm{H}, 5-\mathrm{H}), 6.98(\mathrm{dd}, J=2.9,9.0 \mathrm{~Hz}, 1 \mathrm{H}, 7-\mathrm{H}), 6.78$ (s, 1 $\mathrm{H}, 3-\mathrm{H}), 3.87$ (s, $1 \mathrm{H}, \mathrm{NH}), 3.19$ (t, $\left.J=7.2 \mathrm{~Hz}, 2 \mathrm{H}, 1^{\prime \prime}-\mathrm{H}\right), 1.64$ (m, $\left.2 \mathrm{H}, 2^{\prime \prime}-\mathrm{H}\right), 1.45\left(\mathrm{~m}, 2 \mathrm{H}, 3^{\prime \prime}-\mathrm{H}\right), 0.97$ (t, $J=7.6 \mathrm{~Hz}, 3 \mathrm{H}, 4^{\prime \prime}$ H) ppm. ${ }^{13} \mathrm{C} \mathrm{NMR}\left(\mathrm{CDCl}_{3}\right): \delta=178.6(\mathrm{C}-4), 162.6(\mathrm{C}-2), 149.3$ (C-8a), 146.2 (C-6), 132.2 (C-1'), 131.1 (C-4'), 128.9 (C-3', C-5'), 126.1 (C-2', C-6'), 124.8 (C-4a), 121.2 (C-7), 118.8 (C-8), 106.7 (C5), 103.5 (C-3), 43.9 (C-1' $), 31.4$ (C-2' $), 20.2$ (C-3' $), 13.9$ (C-4' $)$ ppm. IR (KBr): $\tilde{v}=3352,2949,2926,2865,1624,1582,1570,1490$, 1450, 1211, 912, 818, $770 \mathrm{~cm}^{-1}$. MS: $\mathrm{m} / z=293[\mathrm{M}]^{+\cdot}, 250(100 \%)$. $\mathrm{C}_{19} \mathrm{H}_{19} \mathrm{NO}_{2}$ (293.36): calcd. C 77.79, $\mathrm{H} 6.53$, N 4.77; found $\mathrm{C}$ 77.75, H 6.52, N 4.75 .

$\mathrm{N}, \mathrm{N}$-Bis(2-phenyl-4-oxo-4H-chromen-6-yl)butylamine (14): Eluent: toluene/ethyl acetate, $4: 1$; yield $20 \mathrm{mg}(11 \%)$; m.p. $218-220{ }^{\circ} \mathrm{C} .{ }^{1} \mathrm{H}$ $\operatorname{NMR}\left(\mathrm{CDCl}_{3}\right): \delta=7.91(\mathrm{~m}, 4 \mathrm{H}, 4 \mathrm{H}), 7.81(\mathrm{~d}, J=2.7 \mathrm{~Hz}, 2 \mathrm{H})$, $7.53(\mathrm{dd}, J=4.8,1.1 \mathrm{~Hz}, 5 \mathrm{H}), 7.49(\mathrm{~d}, J=9.1 \mathrm{~Hz}, 3 \mathrm{H}), 7.35$ (dd, $J=9.0,2.8 \mathrm{~Hz}, 2 \mathrm{H}), 6.81(\mathrm{~s}, 2 \mathrm{H}), 3.91-3.75$ (m, $2 \mathrm{H}), 1.77-1.61$ $(\mathrm{m}, 2 \mathrm{H}), 1.42(\mathrm{dd}, J=15.0,7.5 \mathrm{~Hz}, 2 \mathrm{H}), 0.95(\mathrm{t}, J=7.3 \mathrm{~Hz}, 3$ H) ppm. ${ }^{13} \mathrm{C} \mathrm{NMR}\left(\mathrm{CDCl}_{3}\right): \delta=178.1(\mathrm{C}-4), 163.1(\mathrm{C}-2), 151.6$ (C-8a), 145.1 (C-6), 131.8 (C-1'), 131.4 (C-4'), 128.9 (C-3', C-5'), 127.9 (C-7), 126.2 (C-2', C-6'), 124.9 (C-4a), 12.2 (C-7), 119.3 (C8), 115.0 (C-5), 106.9 (C-3), 52.7 (C-1"'), 29.4 (C-2' ), 20.2 (C-3"'), 13.9 (C-4') ppm. IR (KBr): $\tilde{v}=3446,3064,2956,2925,2854$, 1632, 1566, 1495, 1480, 1451, 1356, 1259, 910, 818, $770 \mathrm{~cm}^{-1}$. MS: $m / z=326,213(100 \%), 137,105,77,55 . \mathrm{C}_{34} \mathrm{H}_{27} \mathrm{NO}_{4}(513.59)$ : calcd. C 79.51, H 5.30, N 2.73; found C 79.70, H 5.35, N 2.75.

6-[(2-Methylphenyl)amino]flavone (12g): Eluent: toluene/ethyl acetate, 4:1; yield $114 \mathrm{mg}(53 \%)$; m.p. $220-223{ }^{\circ} \mathrm{C} .{ }^{1} \mathrm{H} \mathrm{NMR}\left(\mathrm{CDCl}_{3}+\right.$ [D 6 DMSO): $\delta=7.92$ (m, $\left.2 \mathrm{H}, 2^{\prime}-\mathrm{H}, 6^{\prime}-\mathrm{H}\right), 7.61$ (d, $J=2.5 \mathrm{~Hz}, 1$
H, 5-H), 7.53 (m, 3 H, 3'-H, 5'-H, 4'-H), 7.48 (d, $J=9.0 \mathrm{~Hz}, 1 \mathrm{H}$, 8-H), 7.31 (dd, $J=2.5,9.7 \mathrm{~Hz}, 1 \mathrm{H}, 7-\mathrm{H}), 7.25$ (m, $2 \mathrm{H}, 3^{\prime \prime}-\mathrm{H}, 6^{\prime \prime}{ }_{-}$ $\mathrm{H}), 7.18$ (m, $\left.1 \mathrm{H}, 5^{\prime \prime}-\mathrm{H}\right), 7.01$ (m, $\left.1 \mathrm{H}, 4^{\prime \prime}-\mathrm{H}\right), 6.78$ (s, $\left.1 \mathrm{H}, 3-\mathrm{H}\right)$, $5.88(\mathrm{~s}, 1 \mathrm{H}, \mathrm{NH}), 2.27\left(\mathrm{~s}, 3 \mathrm{H}, 2-\mathrm{CH}_{3}\right) \mathrm{ppm} .{ }^{13} \mathrm{C} \mathrm{NMR}\left(\mathrm{CDCl}_{3}+\right.$ [D 6 DMSO): $\delta=177.1$ (C-4), 161.9 (C-2), 149.2 (C-8a), 142.9 (C$\left.1^{\prime \prime}\right), 140.1$ (C-6), $131.3\left(\mathrm{C}-2^{\prime \prime}\right), 130.8\left(\mathrm{C}-3^{\prime \prime}\right), 130.5$ (C-4'), 130.3 $\left(\mathrm{C}-1^{\prime}\right), 128.5\left(\mathrm{C}-3^{\prime}, \mathrm{C}-5^{\prime}\right), 126.1\left(\mathrm{C}-5^{\prime \prime}\right), 125.6\left(\mathrm{C}-2^{\prime}, \mathrm{C}-6^{\prime}\right), 123.9$ (C-4a), 122.8 (C-4" ), 122.6 (C-6"'), 120.7 (C-7), 118.4 (C-8), 106.9 (C-5), 105.7 (C-3), $17.6\left(2^{\prime \prime}-\mathrm{CH}_{3}\right)$ ppm. IR (KBr): $\tilde{v}=3317,3113$, 3063, 2939, 1641, 1619, 1576, 1534, 1483, 1449, 1365, 1318, 1138 , 914, 832, 770, 755, $690 \mathrm{~cm}^{-1}$. MS: $m / z=326[\mathrm{M}]^{+\cdot}(100 \%), 168$. $\mathrm{C}_{22} \mathrm{H}_{17} \mathrm{NO}_{2}$ (327.38): calcd. C 80.71, $\mathrm{H}$ 5.23, $\mathrm{N} \mathrm{4.28;} \mathrm{found} \mathrm{C}$ 80.69, H 5.20, N 4.26.

6-(Dibutylamino)flavone (12j): Oil, eluent: toluene/ethyl acetate, 8:1; yield $42 \mathrm{mg}(18 \%) .{ }^{1} \mathrm{H}$ NMR $\left(\mathrm{CDCl}_{3}\right): \delta=7.91\left(\mathrm{~m}, 2 \mathrm{H}, 2^{\prime}-\mathrm{H}, 6^{\prime}-\right.$ H), $7.51\left(\mathrm{~m}, 3 \mathrm{H}, 3^{\prime}-\mathrm{H}, 5^{\prime}-\mathrm{H}, 4^{\prime}-\mathrm{H}\right), 7.43$ (d, $J=9.0 \mathrm{~Hz}, 1 \mathrm{H}, 8-$ H), $7.29(\mathrm{~d}, J=2.9 \mathrm{~Hz}, 1 \mathrm{H}, 5-\mathrm{H}), 7.06(\mathrm{dd}, J=2.9,9.0 \mathrm{~Hz}, 1 \mathrm{H}$, 7-H), 6.78 (s, $1 \mathrm{H}, 3-\mathrm{H}), 3.35$ (t, $\left.J=7.6 \mathrm{~Hz}, 4 \mathrm{H}, 1^{\prime \prime}-\mathrm{H}\right), 1.60$ (m, $\left.4 \mathrm{H}, 2^{\prime \prime}-\mathrm{H}\right), 1.38$ (m, $\left.4 \mathrm{H}, 3^{\prime \prime}-\mathrm{H}\right), 0.97$ (t, $\left.J=7.2 \mathrm{~Hz}, 6 \mathrm{H}, 4^{\prime \prime}-\mathrm{H}\right)$ ppm. ${ }^{13} \mathrm{C}$ NMR $\left(\mathrm{CDCl}_{3}\right): \delta=178.8(\mathrm{C}-4), 162.5(\mathrm{C}-2), 148.2(\mathrm{C}-$

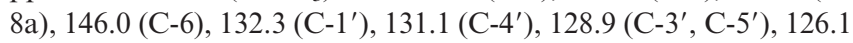
(C-2', C-6'), 124.7 (C-4a), 119.2 (C-7), 118.7 (C-8), 106.4 (C-5), 104.0 (C-3), 50.9 (C-1' $), 29.3\left(\mathrm{C}-2^{\prime \prime}\right), 20.3\left(\mathrm{C}-3^{\prime \prime}\right), 14.0\left(\mathrm{C}-4^{\prime \prime}\right)$ ppm. IR (KBr): $\tilde{v}=3060,2925,2928,2870,1639,1614,1566,1500$, 1453, 1363, 911, 771, $689 \mathrm{~cm}^{-1}$. MS: $m / z=349[\mathrm{M}]^{+*}, 306(100 \%)$.

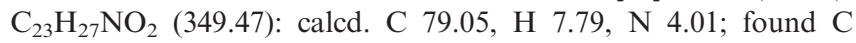
79.07, H 7.81, N 4.02.

6-(Phenyl-methylamino)flavone (12o): Eluent: hexane/ethyl acetate, 4:1; yield $67 \mathrm{mg}$ (31\%); m.p. $164.5-165.5^{\circ} \mathrm{C} .{ }^{1} \mathrm{H}$ NMR $\left(\mathrm{CDCl}_{3}\right): \delta$ $=7.91\left(\mathrm{~m}, 2 \mathrm{H}, 2^{\prime}-\mathrm{H}, 6^{\prime}-\mathrm{H}\right), 7.67(\mathrm{~d}, J=2.5 \mathrm{~Hz}, 1 \mathrm{H}, 5-\mathrm{H}), 7.52$ (m, $\left.3 \mathrm{H}, 3^{\prime}-\mathrm{H}, 5^{\prime}-\mathrm{H}, 4^{\prime}-\mathrm{H}\right), 7.36$ (m, $\left.3 \mathrm{H}, 8-\mathrm{H}, 3^{\prime \prime}-\mathrm{H}, 5^{\prime \prime}-\mathrm{H}\right), 7.28$ (dd, $J=2.9,9.0 \mathrm{~Hz}, 1 \mathrm{H}, 7-\mathrm{H}), 7.10$ (m, $\left.3 \mathrm{H}, 2^{\prime \prime}-\mathrm{H}, 6^{\prime \prime}-\mathrm{H}, 4^{\prime \prime}-\mathrm{H}\right)$, $6.81(\mathrm{~s}, 1 \mathrm{H}, 3-\mathrm{H}), 3.39$ (s, $\left.3 \mathrm{H}, \mathrm{NCH}_{3}\right)$ ppm. ${ }^{13} \mathrm{C} \mathrm{NMR}\left(\mathrm{CDCl}_{3}\right)$ : $\delta=178.3(\mathrm{C}-4), 162.8(\mathrm{C}-2), 150.7\left(\mathrm{C}-1^{\prime \prime}\right), 148.4(\mathrm{C}-8 \mathrm{a}), 146.5(\mathrm{C}-$ 6), $131.9\left(\mathrm{C}-1^{\prime}\right), 131.3\left(\mathrm{C}-4^{\prime}\right), 129.5\left(\mathrm{C}-3^{\prime \prime}, \mathrm{C}-5^{\prime \prime}\right), 128.9$ (C-3', C5'), 126.1 (C-2', C-6'), 125.5 (C-7), 124.6 (C-4a), 123.4 (C-4' $)$, 123.0 (C-2"', C-6"'), 118.6 (C-5), 110.6 (C-8), 106.8 (C-3), 40.7 $\left(\mathrm{NCH}_{3}\right)$ ppm. IR $(\mathrm{KBr}): \tilde{\mathrm{v}}=3448,3037,3002,2951,2890,2815$, 1620, 1590, 1580, 1566, 1482, 1457, 1450, 1362, 1141, 1134, 1045, 1029, 912, 832, 821, 770, $707 \mathrm{~cm}^{-1}$. MS: $m / z=327[\mathrm{M}]^{+*}, 326$ (100\%). $\mathrm{C}_{22} \mathrm{H}_{17} \mathrm{NO}_{2}$ (327.38): calcd. C 80.71, H 5.23, N 4.28; found C 80.69, H 5.20, N 4.28.

7-(Butylamino)flavone (18a): Eluent: toluene/ethyl acetate, 8:1; yield $157 \mathrm{mg}(81 \%)$ from 17, $63 \mathrm{mg}(32 \%)$ from 22; m.p. $163.5-164.5^{\circ} \mathrm{C}$. ${ }^{1} \mathrm{H}$ NMR $\left(\mathrm{CDCl}_{3}\right): \delta=7.96(\mathrm{~d}, J=8.6 \mathrm{~Hz}, 1 \mathrm{H}, 5-\mathrm{H}), 7.88(\mathrm{~m}, 2$ H, 2'-H, 6'-H), 7.49 (m, 3 H, 3'-H, 5'-H, 4'-H), 6.69 (s, 1 H, 3-H), $6.62(\mathrm{~d}, J=8.6 \mathrm{~Hz}, 1 \mathrm{H}, 6-\mathrm{H}), 6.52(\mathrm{~s}, 1 \mathrm{H}, 8-\mathrm{H}), 4.50(\mathrm{~s}, 1 \mathrm{H}$, $\mathrm{NH}), 3.21$ (q, $\left.J=6.8 \mathrm{~Hz}, 2 \mathrm{H}, 1^{\prime \prime}-\mathrm{H}\right), 1.65\left(\mathrm{~m}, 2 \mathrm{H}, 2^{\prime \prime}-\mathrm{H}\right), 1.46$ $\left(\mathrm{m}, 2 \mathrm{H}, 3^{\prime \prime}-\mathrm{H}\right), 0.98\left(\mathrm{t}, J=7.6 \mathrm{~Hz}, 3 \mathrm{H}, 4^{\prime \prime}-\mathrm{H}\right) \mathrm{ppm} .{ }^{13} \mathrm{C} \mathrm{NMR}$ $\left(\mathrm{CDCl}_{3}\right): \delta=177.6(\mathrm{C}-4), 162.0(\mathrm{C}-2), 158.8$ (C-8a), $153.2(\mathrm{C}-7)$, $132.1\left(\mathrm{C}-1^{\prime}\right), 104.0\left(\mathrm{C}-4^{\prime}\right), 128.8$ (C-3', C-5'), 126.5 (C-5), 125.9 (C2', C-6'), 114.3 (C-4a), 112.9 (C-6), 107.2 (C-3), 96.2 (C-8), 43.1 $\left(\mathrm{C}-1^{\prime \prime}\right), 31.1\left(\mathrm{C}-2^{\prime \prime}\right), 20.2\left(\mathrm{C}-3^{\prime \prime}\right), 13.8\left(\mathrm{C}-4^{\prime \prime}\right)$ ppm. IR (KBr): $\tilde{v}=$ 3316, 3139, 3069, 3034, 2948, 2927, 2865, 1632, 1586, 1566, 1503, 1448, 1378, 1248, 1095, 906, 824, 764, $670 \mathrm{~cm}^{-1}$. MS: $\mathrm{m} / \mathrm{z}=293$ $[\mathrm{M}]^{+\cdot}, 250$ (100\%). $\mathrm{C}_{19} \mathrm{H}_{19} \mathrm{NO}_{2}$ (293.36): calcd. C 77.79, H 6.53, N 4.77; found C 77.76, H 6.55, N 4.78.

7-[(4-Chlorophenyl)amino|flavone (18f): Eluent: toluene/ethyl acetate, $4: 1$; yield $126 \mathrm{mg}(55 \%)$ from 17, $83 \mathrm{mg}$ (36\%) from 22; m.p. 273.5-276.5 ${ }^{\circ} \mathrm{C} .{ }^{1} \mathrm{H} \mathrm{NMR}\left(\mathrm{CDCl}_{3}+\left[\mathrm{D}_{6}\right] \mathrm{DMSO}\right): \delta=8.36(\mathrm{~s}, 1 \mathrm{H}$, $\mathrm{NH}), 7.99$ (d, $J=8.6 \mathrm{~Hz}, 1 \mathrm{H}, 5-\mathrm{H}), 7.90$ (m, $\left.2 \mathrm{H}, 2^{\prime}-\mathrm{H}, 6^{\prime}-\mathrm{H}\right)$, $7.53\left(\mathrm{~m}, 3 \mathrm{H}, 3^{\prime}-\mathrm{H}, 5^{\prime}-\mathrm{H}, 4^{\prime}-\mathrm{H}\right), 7.33$ (d, $J=8.6 \mathrm{~Hz}, 2 \mathrm{H}, 3^{\prime \prime}-\mathrm{H}$, 
$\left.5^{\prime \prime}-\mathrm{H}\right), 7.23\left(\mathrm{~d}, J=8.6 \mathrm{~Hz}, 2 \mathrm{H}, 2^{\prime \prime}-\mathrm{H}, 6^{\prime \prime}-\mathrm{H}\right), 7.09$ (s, $\left.1 \mathrm{H}, 8-\mathrm{H}\right)$, 7.02 (d, $J=8.6 \mathrm{~Hz}, 1 \mathrm{H}, 6-\mathrm{H}), 6.70(\mathrm{~s}, 1 \mathrm{H}, 3-\mathrm{H}) \mathrm{ppm} .{ }^{13} \mathrm{C}$ NMR $\left(\mathrm{CDCl}_{3}+\left[\mathrm{D}_{6}\right] \mathrm{DMSO}\right): \delta=176.7(\mathrm{C}-4), 161.8(\mathrm{C}-2), 157.6(\mathrm{C}-8 \mathrm{a})$, 149.1 (C-7), $139.0\left(\mathrm{C}-1^{\prime \prime}\right), 131.3\left(\mathrm{C}-1^{\prime}\right), 130.6\left(\mathrm{C}-4^{\prime}\right), 128.7\left(\mathrm{C}-2^{\prime}\right.$, C-6'), 128.3 (C-3' $\left.{ }^{\prime \prime}, \mathrm{C}-5^{\prime \prime}\right), 126.9$ (C-4' $), 126.0$ (C-5), 125.4 (C-2', C-6'), 121.3 (C-2"', C-6"'), 115.5 (C-4a), 114.2 (C-6), 106.6 (C-3), 99.2 (C-8) ppm. IR (KBr): $\tilde{v}=3274,3188,3100,1648,1627,1585$, 1534, 1492, 1449, 1438, 1374, 1092, 909, 813, 768, $676 \mathrm{~cm}^{-1}$. MS: $m / z=347[\mathrm{M}]^{+\cdot}(100 \%), 319 . \mathrm{C}_{21} \mathrm{H}_{14} \mathrm{ClNO}_{2}$ (347.80): calcd. $\mathrm{C}$ 72.52, H 4.06, $\mathrm{Cl} 10.19, \mathrm{~N} 4.03$; found $\mathrm{C} 72.55, \mathrm{H} \mathrm{4.10,} \mathrm{Cl} 10.21$, $\mathrm{N} 4.01$.

7-Morpholinoflavone (18k): Eluent: toluene/ethyl acetate, 4:1; yield $150 \mathrm{mg}(74 \%)$; m.p. $208-211.5{ }^{\circ} \mathrm{C} .{ }^{1} \mathrm{H}$ NMR $\left(\mathrm{CDCl}_{3}\right): \delta=8.07(\mathrm{~d}$, $J=9.0 \mathrm{~Hz}, 1 \mathrm{H}, 5-\mathrm{H}), 7.89$ (m, $\left.2 \mathrm{H}, 2^{\prime}-\mathrm{H}, 6^{\prime}-\mathrm{H}\right), 7.51$ (m, $3 \mathrm{H}, 3^{\prime}-$ $\left.\mathrm{H}, 5^{\prime}-\mathrm{H}, 4^{\prime}-\mathrm{H}\right), 6.96(\mathrm{dd}, J=2.2,9.0 \mathrm{~Hz}, 1 \mathrm{H}, 6-\mathrm{H}), 6.83$ (s, $J=$ $2.2 \mathrm{~Hz}, 1 \mathrm{H}, 8-\mathrm{H}), 6.73$ (s, $1 \mathrm{H}, 3-\mathrm{H}), 3.89$ (m, $\left.4 \mathrm{H}, 3^{\prime \prime}-\mathrm{H}, 5^{\prime \prime}-\mathrm{H}\right)$, $3.36\left(\mathrm{~m}, 4 \mathrm{H}, 2^{\prime \prime}-\mathrm{H}, 6{ }^{\prime \prime}-\mathrm{H}\right) \mathrm{ppm} .{ }^{13} \mathrm{C} \mathrm{NMR}\left(\mathrm{CDCl}_{3}\right): \delta=177.7(\mathrm{C}-$ 4), 162.6 (C-2), 158.1 (C-8a), 155.0 (C-7), 132.0 (C-1'), 131.2 (C$\left.4^{\prime}\right), 128.9\left(\mathrm{C}-3^{\prime}, \mathrm{C}-5^{\prime}\right), 126.6(\mathrm{C}-5), 126.0\left(\mathrm{C}-2^{\prime}, \mathrm{C}-6^{\prime}\right), 115.9$ (C4a), 112.9 (C-6), 107.4 (C-3), 100.3 (C-8), 66.4 (C-3"', C-5' '), 47.6 $\left(\mathrm{C}-2^{\prime \prime}, \mathrm{C}-6^{\prime \prime}\right)$ ppm. IR $(\mathrm{KBr}): \tilde{v}=3432,3060,2963,2855,1632$, 1592, 1573, 1511, 1494, 1448, 1383, 1239, 1124, 819, $772 \mathrm{~cm}^{-1}$. MS: $m / z=307[\mathrm{M}]^{+\cdot}(100 \%), 249,222,147,91 . \mathrm{C}_{19} \mathrm{H}_{17} \mathrm{NO}_{3}$ (307.35): calcd. C 74.25, H 5.58, N 4.56; found C 74.24, H 5.60, N 4.54.

\section{3-Hydroxy-1-(5-bromo-2-hydroxyphenyl)-3-phenylprop-2-en-1-one} (15):

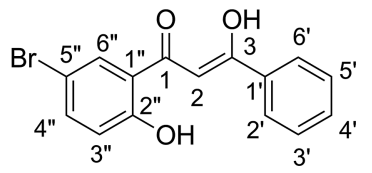

Eluent: toluene/ethyl acetate, 4:1; yield $17 \mathrm{mg}$ (7.7\%); m.p. 112$115^{\circ} \mathrm{C}$. This compound was obtained as a by-product from the reaction of tert-butylamine and 6-bromoflavone. ${ }^{1} \mathrm{H}$ NMR $\left(\mathrm{CDCl}_{3}\right): \delta=15.48\left(\mathrm{~s}, 1 \mathrm{H}, 2^{\prime \prime}-\mathrm{OH}\right), 12.06(\mathrm{~s}, 1 \mathrm{H}, 3-\mathrm{OH}), 7.96(\mathrm{~d}$, $\left.J=7.2 \mathrm{~Hz}, 2 \mathrm{H}, 2^{\prime}-\mathrm{H}, 6^{\prime}-\mathrm{H}\right), 7.85$ (s, $\left.1 \mathrm{H}, 6^{\prime \prime}-\mathrm{H}\right), 7.57$ (d, $J=$ $\left.7.2 \mathrm{~Hz}, 1 \mathrm{H}, 4^{\prime \prime}-\mathrm{H}\right), 7.52\left(\mathrm{~m}, 3 \mathrm{H}, 3^{\prime}-\mathrm{H}, 5^{\prime}-\mathrm{H}, 4^{\prime}-\mathrm{H}\right), 6.90(\mathrm{~d}, J=$ $\left.9.0 \mathrm{~Hz}, 1 \mathrm{H}, 3^{\prime \prime}-\mathrm{H}\right), 6.75$ (s, $\left.1 \mathrm{H}, 2-\mathrm{H}\right) \mathrm{ppm} .{ }^{13} \mathrm{C} \mathrm{NMR}\left(\mathrm{CDCl}_{3}\right): \delta$ $=194.2(\mathrm{C}-1), 178.4(\mathrm{C}-3), 161.3\left(\mathrm{C}-2^{\prime \prime}\right), 138.3\left(\mathrm{C}-4^{\prime \prime}\right), 133.2(\mathrm{C}-$ $\left.1^{\prime}\right), 132.8\left(\mathrm{C}-6^{\prime \prime}\right), 130.6\left(\mathrm{C}-4^{\prime}\right), 128.8$ (C-2', C-6'), 127.0 (C-3', C$\left.5^{\prime}\right), 120.8\left(\mathrm{C}-3^{\prime \prime}\right), 120.3\left(\mathrm{C}-1^{\prime \prime}\right), 110.7\left(\mathrm{C}-5^{\prime \prime}\right), 92.1$ (C-2) ppm. IR $(\mathrm{KBr}): \tilde{v}=1607,1567,1469,1289,1190,913,744 \mathrm{~cm}^{-1}$.

7-(Butylamino)-4' -methoxyflavone (20a): Eluent: toluene/ethyl acetate, $1: 1$; yield $178 \mathrm{mg}(84 \%)$; m.p. $173.5-175.5{ }^{\circ} \mathrm{C} .{ }^{1} \mathrm{H}$ NMR $\left(\mathrm{CDCl}_{3}\right): \delta=7.95(\mathrm{~d}, J=9.0 \mathrm{~Hz}, 1 \mathrm{H}, 5-\mathrm{H}), 7.83(\mathrm{~d}, J=8.6 \mathrm{~Hz}, 2$ H, 2'-H, 6'-H), 6.99 (d, $\left.J=8.6 \mathrm{~Hz}, 2 \mathrm{H}, 3^{\prime}-\mathrm{H}, 5^{\prime}-\mathrm{H}\right), 6.59$ (m, 2 $\mathrm{H}, 3-\mathrm{H}, 6-\mathrm{H}), 6.50$ (d, $J=1.8 \mathrm{~Hz}, 1 \mathrm{H}, 8-\mathrm{H}), 4.42(\mathrm{~s}, 1 \mathrm{H}, \mathrm{NH})$, $3.87\left(\mathrm{~s}, 3 \mathrm{H}, 4^{\prime}-\mathrm{OCH}_{3}\right), 3.20\left(\mathrm{~m}, 2 \mathrm{H}, 1^{\prime \prime}-\mathrm{H}\right), 1.66\left(\mathrm{~m}, 2 \mathrm{H}, 2^{\prime \prime}-\mathrm{H}\right)$, $1.46\left(\mathrm{~m}, 2 \mathrm{H}, 3^{\prime \prime}-\mathrm{H}\right), 0.98\left(\mathrm{t}, J=7.6 \mathrm{~Hz}, 3 \mathrm{H}, 4^{\prime \prime}-\mathrm{H}\right) \mathrm{ppm} .{ }^{13} \mathrm{C}$ NMR $\left(\mathrm{CDCl}_{3}\right): \delta=177.7(\mathrm{C}-4), 162.1(\mathrm{C}-2), 161.9\left(\mathrm{C}-4^{\prime}\right), 158.7$ (C-8a), 153.0 (C-7), 127.6 (C-2', C-6'), 126.5 (C-5), $124.5\left(\mathrm{C}-1^{\prime}\right)$, 114.4 (C-4a), 114.2 (C-3', C-5'), 112.7 (C-6), 105.9 (C-3), 96.3 (C8), $55.4\left(4^{\prime}-\mathrm{OCH}_{3}\right), 43.2\left(\mathrm{C}-1^{\prime \prime}\right), 31.2\left(\mathrm{C}-2^{\prime \prime}\right), 20.2\left(\mathrm{C}-3^{\prime \prime}\right), 13.81$ $\left(\mathrm{C}-4^{\prime \prime}\right)$ ppm. IR (KBr): $\tilde{v}=3302,2950,2929,2860,1624,1608$, 1584, 1566, 1537, 1508,1423,1376, 1244, 1176, 1095, 909, 822, $597 \mathrm{~cm}^{-1}$. MS: $m / z=323[\mathrm{M}]^{+*}, 280(100 \%), 148 . \mathrm{C}_{20} \mathrm{H}_{21} \mathrm{NO}_{3}$ (323.39): calcd. C 74.28, H 6.55, N 4.33; found C 74.25, H 6.58, N 4.35 .

3-(Butylamino)flavone (24a): Yellow oil, eluent: hexane/ethyl acetate, $3: 1$; yield $64 \mathrm{mg}(33 \%) .{ }^{1} \mathrm{H}$ NMR $\left(\mathrm{CDCl}_{3}\right): \delta=8.24(\mathrm{~d}, J=$ $7.9 \mathrm{~Hz}, 1 \mathrm{H}, 5-\mathrm{H}), 7.96$ (d, $\left.J=7.2 \mathrm{~Hz}, 2 \mathrm{H}, 2^{\prime}-\mathrm{H}, 6^{\prime}-\mathrm{H}\right), 7.60$ (t, $J$
$=7.2 \mathrm{~Hz}, 1 \mathrm{H}, 7-\mathrm{H}), 7.40-7.51\left(\mathrm{~m}, 4 \mathrm{H}, 6-\mathrm{H}, 8-\mathrm{H}, 3^{\prime}-\mathrm{H}, 5^{\prime}-\mathrm{H}\right)$, $7.36\left(\mathrm{~m}, 1 \mathrm{H}, 4^{\prime}-\mathrm{H}\right), 4.41(\mathrm{~s}, 1 \mathrm{H}, \mathrm{NH}), 2.64(\mathrm{t}, J=6.8 \mathrm{~Hz}, 2 \mathrm{H}$, $\left.1^{\prime \prime}-\mathrm{H}\right), 1.36-1.42$ (m, $\left.2 \mathrm{H}, 2^{\prime \prime}-\mathrm{H}\right), 1.21-1.29$ (m, $\left.2 \mathrm{H}, 3^{\prime \prime}-\mathrm{H}\right), 0.79$ (t, $\left.J=7.5 \mathrm{~Hz}, 3 \mathrm{H}, 4^{\prime \prime}{ }^{\prime} \mathrm{H}\right) \mathrm{ppm} .{ }^{13} \mathrm{C} \mathrm{NMR}\left(\mathrm{CDCl}_{3}\right): \delta=175.3(\mathrm{C}-$ 4), 155.5 (C-8a), 147.7 (C-2), 133.5 (C-4a), 132.9 (C-7), 131.6 (C1), 129.6 (C-5), 128.3 (C-2', C-6'), 128.1 (C-3', C-5'), 125.8 (C-4'), 124.0 (C-6), 120.9 (C-3), 117.9 (C-8), 47.0 (C-1' '), 32.3 (C-2' '), 19.9 $\left(\mathrm{C}-3^{\prime \prime}\right), 13.8\left(\mathrm{C}-4^{\prime \prime}\right)$ ppm. IR $(\mathrm{KBr}): \tilde{v}=3326,2957,2928,2871$, 2358, 1613, 1465, 1195, $757 \mathrm{~cm}^{-1}$. MS: $m / z=293[\mathrm{M}]^{+\cdot}, 250$ (100\%). $\mathrm{C}_{24} \mathrm{H}_{19} \mathrm{NO}_{2}$ (353.42): calcd. C 81.56, H 5.42, N 3.96; found C $81.60, \mathrm{H} 5.45, \mathrm{~N} 3.93$.

3- $\mathrm{N}$-Pyrrolidinoflavone (24d): Oil, eluent: hexane/ethyl acetate, 3:1; yield $26 \mathrm{mg}(13 \%) .{ }^{1} \mathrm{H}$ NMR $\left(\mathrm{CDCl}_{3}\right): \delta=8.22(\mathrm{~d}, J=7.9 \mathrm{~Hz}, 1$ $\mathrm{H}, 5-\mathrm{H}), 8.01\left(\mathrm{~d}, J=7.2 \mathrm{~Hz}, 2 \mathrm{H}, 2^{\prime}-\mathrm{H}, 6^{\prime}-\mathrm{H}\right), 7.64(\mathrm{~m}, 1 \mathrm{H}, 7-\mathrm{H})$, 7.47-7.50 (m, 4 H, 6-H, 8-H, 3'-H, 5'-H), 7.37 (m, 1 H, 4'-H), 3.16 (m, 4 H, 2' $\left.{ }^{\prime \prime}-\mathrm{H}, 5^{\prime \prime}-\mathrm{H}\right), 1.94$ (m, $\left.4 \mathrm{H}, 3^{\prime \prime}-\mathrm{H}, 4^{\prime \prime}-\mathrm{H}\right) \mathrm{ppm} .{ }^{13} \mathrm{C}$ NMR $\left(\mathrm{CDCl}_{3}\right): \delta=177.9(\mathrm{C}-4), 161.9(\mathrm{C}-8 \mathrm{a}), 155.4(\mathrm{C}-2), 133.1(\mathrm{C}-7)$, 132.9 (C-1'), 130.4 (C-4a), 130.0 (C-5), 128.7 (C-2', C-6'), 128.0 (C-3', C-5'), 125.6 (C-4'), 124.5 (C-6), 124.3 (C-3), 117.9 (C-8), 50.6 (C-2"', C-5'), 26.3 (C-3"', C-4"') ppm. IR (KBr): $\tilde{v}=3437$, 2929, 2851, 1615, 1602, 1466, 1376, 1307, 1198, 754, $689 \mathrm{~cm}^{-1}$. MS: $m / z=291[\mathrm{M}]^{+\cdot}(100 \%), 248,222,194,165,120 . \mathrm{C}_{19} \mathrm{H}_{17} \mathrm{NO}_{2}$ (291.35): calcd. C 78.33, H 5.88, N 4.81; found C 78.37, H 5.90, N 4.80 .

Buchwald-Hartwig Cross-Coupling of 3-Bromoflavone (23) by Microwave Activation: A mixture of 3-bromoflavone $(23 ; 100 \mathrm{mg}$, $0.330 \mathrm{mmol}), n$-butylamine $(40 \mu \mathrm{L}, 0.400 \mathrm{mmol}), \mathrm{NaO} t \mathrm{Bu}(44 \mathrm{mg}$, $0.46 \mathrm{mmol})$, and BINAP (15 mg, $0.025 \mathrm{mmol})$ in toluene $(3 \mathrm{~mL})$ in a capped vial $(10 \mathrm{~mL})$ was irradiated for $15 \mathrm{~min}\left(200 \mathrm{~W}, 110^{\circ} \mathrm{C}\right)$. Then the mixture was cooled, water was added $(10 \mathrm{~mL})$, and the mixture was extracted with ethyl acetate $(2 \times 25 \mathrm{~mL})$. The combined organic layers were washed with water, and dried (magnesium sulfate), and the solvent was evaporated in vacuo. The crude product was purified by column chromatography (hexane/ethyl acetate, 4:1) to give $\mathbf{2 4 a}(26 \mathrm{mg}, 27 \%$ ) as a yellow oil.

Alkylation of 3-Aminoflavone (26) by Microwave Activation: A mixture of 3-aminoflavone (26; $474 \mathrm{mg}, 2.000 \mathrm{mmol})$, butyl bromide $(603 \mathrm{mg}, 4.400 \mathrm{mmol})$, and potassium carbonate $(608 \mathrm{mg}$, $4.400 \mathrm{mmol})$ in water $(4 \mathrm{~mL})$ was irradiated for $60 \mathrm{~min}(100 \mathrm{~W}$, $\left.120^{\circ} \mathrm{C}\right)$ in a capped vial $(10 \mathrm{~mL})$. Then, the mixture was cooled and extracted with ethyl acetate $(2 \times 25 \mathrm{~mL})$. The combined organic layers were washed with water, and dried (magnesium sulfate), and the solvent was evaporated in vacuo. The crude product was purified by column chromatography (hexane/ethyl acetate, 4:1) to give 24a (114 mg, 19\%) as a yellow oil.

Ring Contraction: A mixture of 3-bromoflavone (100 mg, $0.33 \mathrm{mmol}$ ) and amine ( $0.825 \mathrm{mmol}, 2.5$ equiv. $)$ in THF was stirred for $1 \mathrm{~d}$ at ambient temperature according to the literature procedure. ${ }^{[45]}$ Then the solvent was evaporated, and the crude reaction mixture was submitted directly to a silica gel column to give the pure product.

2-[ $\alpha$-(Butylamino)benzylidene]benzofuran-3(2H)-one (25a): Yellow oil, eluent: hexane/ethyl acetate, 5:1; yield $71 \mathrm{mg}(74 \%) .{ }^{1} \mathrm{H}$ NMR $\left(\mathrm{CDCl}_{3}\right): \delta=10.02(\mathrm{~s}, 1 \mathrm{H}, \mathrm{NH}), 7.84(\mathrm{~d}, J=7.6 \mathrm{~Hz}, 1 \mathrm{H}, 5-\mathrm{H})$, $7.50\left(\mathrm{~m}, 5 \mathrm{H}, 2^{\prime}-\mathrm{H}, 3^{\prime}-\mathrm{H}, 4^{\prime}-\mathrm{H}, 5^{\prime}-\mathrm{H}, 6^{\prime}-\mathrm{H}\right), 7.42(\mathrm{t}, J=7.8 \mathrm{~Hz}, 1$ $\mathrm{H}, 7-\mathrm{H}), 7.13(\mathrm{~m}, 2 \mathrm{H}, 6-\mathrm{H}, 8-\mathrm{H}), 3.23\left(\mathrm{t}, J=6.8 \mathrm{~Hz}, 2 \mathrm{H}, 1^{\prime \prime}-\mathrm{H}\right)$, $1.56\left(\mathrm{~m}, 2 \mathrm{H}, 2^{\prime \prime}-\mathrm{H}\right), 1.38\left(\mathrm{~m}, 2 \mathrm{H}, 3^{\prime \prime}-\mathrm{H}\right), 0.87(\mathrm{t}, J=7.3 \mathrm{~Hz}, 3$ $\left.\mathrm{H}, 4^{\prime \prime}-\mathrm{H}\right) \mathrm{ppm} .{ }^{13} \mathrm{C} \mathrm{NMR}\left(\mathrm{CDCl}_{3}\right): \delta=177.5,160.8,152.2,132.0$, $131.7,130.2,129.7,128.9,128.6,124.7,122.8,121.6,112.5,44.2$, 32.7, 29.6, 19.7, $13.6 \mathrm{ppm}$. IR (KBr): $\tilde{v}=3368,3065,2960,2932$, $2873,1702,1632,1603,1458,1381,1250,755,713 \mathrm{~cm}^{-1}$. MS: $\mathrm{m} / \mathrm{z}$ 
$=293[\mathrm{M}]^{+*}, 250(100 \%) \cdot \mathrm{C}_{19} \mathrm{H}_{19} \mathrm{NO}_{2}$ (293.36): calcd. $\mathrm{C} 77.79, \mathrm{H}$ 6.53, N 4.77; found C 77.82, H 6.55, N 4.80.

General Procedure for the Synthesis of 6- and 7-(Diphenylmethyleneamino)flavones (27a and 27b): A mixture of 6-bromo- (11) or 7-bromoflavone $(\mathbf{1 7} ; 1.505 \mathrm{~g}, 5.00 \mathrm{mmol})$, BINAP $(235 \mathrm{mg}$, $0.375 \mathrm{mmol})$, benzophenone imine $(2 ; 1.10 \mathrm{~mL}, 6.00 \mathrm{mmol})$, palladium acetate ( $55 \mathrm{mg}, 0.250 \mathrm{mmol}, 5 \mathrm{~mol}-\%$ ), and cesium carbonate $(2.120 \mathrm{~g}, 6.50 \mathrm{mmol})$ in xylene $(30 \mathrm{~mL})$ was stirred at reflux overnight under a nitrogen atmosphere. The cooled mixture was poured into water $(100 \mathrm{~mL})$, then extracted with ethyl acetate $(3 \times 25 \mathrm{~mL})$. The combined organic phases were dried with magnesium sulfate, then the solvents were removed in vacuo. The solid residue was triturated with a mixture of hexane $(20 \mathrm{~mL})$ and acetone $(1 \mathrm{~mL})$ to give pure $27 \mathbf{a}$ or $\mathbf{2 7} \mathbf{b}$ as a pale yellow solid.

7-I(Diphenylmethylene)imino]flavone (27b): Yield 73\%; m.p. 212$213{ }^{\circ} \mathrm{C} .{ }^{1} \mathrm{H}$ NMR $\left(\mathrm{CDCl}_{3}\right): \delta=7.99(\mathrm{~d}, J=8.6 \mathrm{~Hz}, 1 \mathrm{H}, 5-\mathrm{H}), 7.85$ $(\mathrm{m}, 2 \mathrm{H}, \mathrm{Ph}), 7.77(\mathrm{~m}, 2 \mathrm{H}, \mathrm{Ph}), 7.51(\mathrm{~m}, 6 \mathrm{H}, \mathrm{Ph}), 7.45(\mathrm{~d}, J=$ $8.6 \mathrm{~Hz}, 1 \mathrm{H}, 6-\mathrm{H}), 7.29$ (m, $3 \mathrm{H}, \mathrm{Ph}), 7.17$ (m, $2 \mathrm{H}, \mathrm{Ph}), 6.90$ (s, 1 $\mathrm{H}, 8-\mathrm{H}), 6.74(\mathrm{~s}, 1 \mathrm{H}, 3-\mathrm{H}) \mathrm{ppm} .{ }^{13} \mathrm{C} \mathrm{NMR}\left(\mathrm{CDCl}_{3}\right): \delta=178.0(\mathrm{C}-$ 4), $169.5(\mathrm{C}=\mathrm{N}), 162.9(\mathrm{C}-2), 156.8(\mathrm{C}-8 \mathrm{a}), 138.6(\mathrm{C}-7), 135.2,137.5$ $\left(\mathrm{C}-1^{\prime \prime}\right), 131.8\left(\mathrm{C}-1^{\prime}\right), 132.4,131.4,130.0,129.8,129.5,129.1,128.3$ (Ph), 126.1 (C-7), 119.4 (C-4a), 119.0 (C-5), 108.5, 107.5 (C-3, C8) ppm. IR (KBr): $\tilde{v}=3455,3068,1640,1617,1458,1358,1289$, 1024, 910, 773, $697 \mathrm{~cm}^{-1}$. MS: $m / z=401[\mathrm{M}]^{+\cdot}, 324,297,221,165$ (100\%), 139, 102, 77. $\mathrm{C}_{28} \mathrm{H}_{19} \mathrm{NO}_{2}$ (401.46): calcd. C 83.77, $\mathrm{H} 4.77$; found $\mathrm{C} 83.80, \mathrm{H}$ 4.75. $\mathrm{C}_{28} \mathrm{H}_{19} \mathrm{NO}_{2}$ (401.46): calcd. $\mathrm{C}$ 83.77, $\mathrm{H}$ 4.77, N 3.49; found C 83.80, H 4.75, N 3.54.

General Procedure for the Synthesis of 6- and 7-Aminoflavones (28a and 28b): [(Diphenylmethylene)imino]flavone $27 \mathrm{a}$ or $27 \mathrm{~b}(1.466 \mathrm{~g}$, $3.651 \mathrm{mmol})$ was dissolved in THF $(14 \mathrm{~mL})$, and $\mathrm{HCl}(6 \mathrm{~N}$ aq.; $9.2 \mathrm{~mL}, 18.0 \mathrm{mmol}, 5$ equiv.) was added. After $10 \mathrm{~min}$, dichloromethane $(25 \mathrm{~mL})$ and water $(50 \mathrm{~mL})$ were added, and then the mixture was stirred at room temperature overnight. Next, dichloromethane $(10 \mathrm{~mL})$ was added, upon which the reaction mixture became clear. The $\mathrm{pH}$ was adjusted to ca. 9-10 by the addition of saturated sodium hydrogen carbonate solution (vigorous evolution of gas!). The product was extracted with dichloromethane $(3 \times$ $50 \mathrm{~mL}$ ). The combined organic extracts were dried with magnesium sulfate, and the solvent was evaporated in vacuo. The solid residue was triturated with a mixture of hexane $(20 \mathrm{~mL})$ and acetone ( $1 \mathrm{~mL}$ ) to give pure amine $\mathbf{2 8 a}$ or $\mathbf{2 8 b}$ as a pale yellow solid.

7-Aminoflavone (28b): Yield $68 \%$; m.p. $183-185{ }^{\circ} \mathrm{C}$, lit. m.p. ${ }^{[5]}$ $186{ }^{\circ} \mathrm{C} .{ }^{1} \mathrm{H} \mathrm{NMR}\left(\mathrm{CDCl}_{3}\right): \delta=8.01(\mathrm{~d}, J=9.2 \mathrm{~Hz}, 1 \mathrm{H}, 5-\mathrm{H}), 7.87$ (m, $\left.2 \mathrm{H}, 2^{\prime}-\mathrm{H}, 6^{\prime}-\mathrm{H}\right), 7.50$ (m, $\left.3 \mathrm{H}, 3^{\prime}-\mathrm{H}, 5^{\prime}-\mathrm{H}, 4^{\prime}-\mathrm{H}\right), 6.69$ (m, 3 $\mathrm{H}, 3-\mathrm{H}, 6-\mathrm{H}, 8-\mathrm{H}), 4.33$ (br. s, $\left.2 \mathrm{H}, \mathrm{NH}_{2}\right) \mathrm{ppm} .{ }^{13} \mathrm{C} \mathrm{NMR}\left(\mathrm{CDCl}_{3}\right)$ : $\delta=177.7$ (C-4), 162.4 (C-2), 158.3 (C-7), 151.9 (C-8a), 132.0 (C$\left.1^{\prime}\right), 131.2$ (C-5), 128.9 (C-3', C-5'), 127.2 (C-4'), 126.1 (C-2', C6'), 115.7 (C-4a), 113.7 (C-6), 107.3 (C-3), 100.2 (C-8) ppm. IR $(\mathrm{KBr}): \tilde{v}=3462,3332,3194,1633,1586,1569,1450,1388,1370$, 1248, 1186, 1026, 909, 832, $768 \mathrm{~cm}^{-1}$. MS: $m / z=237[\mathrm{M}]^{+\cdot}, 209$, 180, 152, 135, 107, 79. $\mathrm{C}_{15} \mathrm{H}_{11} \mathrm{NO}_{2}$ (237.26): calcd. C 75.94, H 4.67, N 5.90; found C 75.95, H 4.69, N 5.95.

General Method for Coupling 6- and 7-Bromoflavone with Amino Acid Methyl Ester Hydrochlorides: Bromoflavone 11 or 17 (0.66 mmol), cesium carbonate $(557 \mathrm{mg}, 1.71 \mathrm{mmol})$, BINAP (32 $\mathrm{mg}, 0.050 \mathrm{mmol}$ ), and the amino acid methyl ester hydrochloride $(0.80 \mathrm{mmol})$ were mixed in dry xylene $(6 \mathrm{~mL})$ in an oven-dried flask under nitrogen, and $\mathrm{Pd}(\mathrm{OAc})_{2}(7 \mathrm{mg}, 0.032 \mathrm{mmol})$ was added. The reaction mixture was stirred at reflux at $135^{\circ} \mathrm{C}$ for $24 \mathrm{~h}$ in an oil bath. The crude reaction mixture was applied directly to a silica gel column to give the pure cross-coupled product.

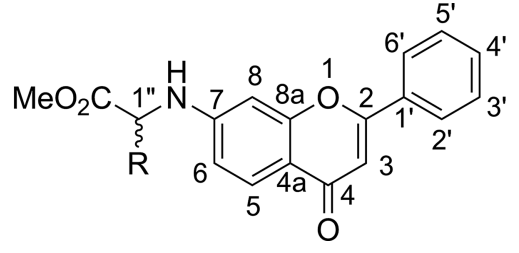

7-\{[2-Phenyl-1-(methoxycarbonyl)ethyl|amino\}flavone (31a): Eluent: toluene/ethyl acetate, $2: 1$; yield $168 \mathrm{mg}(64 \%)$; m.p. $171.5-173.5^{\circ} \mathrm{C}$. ${ }^{1} \mathrm{H}$ NMR $\left(\mathrm{CDCl}_{3}\right): \delta=8.00(\mathrm{~d}, J=8.6 \mathrm{~Hz}, 1 \mathrm{H}, 5-\mathrm{H}), 7.88(\mathrm{~m}, 2$ $\left.\mathrm{H}, 2^{\prime}-\mathrm{H}, 6^{\prime}-\mathrm{H}\right), 7.51$ (m, $\left.3 \mathrm{H}, 3^{\prime}-\mathrm{H}, 5-\mathrm{H}, 4^{\prime}-\mathrm{H}\right), 7.31$ (m, $3 \mathrm{H}, 3^{\prime \prime \prime}$ $\left.\mathrm{H}, 5^{\prime \prime \prime}-\mathrm{H}, 4^{\prime \prime \prime}-\mathrm{H}\right), 7.15$ (m, $\left.2 \mathrm{H}, 2^{\prime \prime \prime}-\mathrm{H}, 6^{\prime \prime \prime}-\mathrm{H}\right), 6.71$ (s, $1 \mathrm{H}, 3-$ $\mathrm{H}), 6.64(\mathrm{dd}, J=1.8,8.6 \mathrm{~Hz}, 1 \mathrm{H}, 6-\mathrm{H}), 6.54(\mathrm{~s}, 1 \mathrm{H}, 8-\mathrm{H}), 4.83$ (d, $J=7.9 \mathrm{~Hz}, 1 \mathrm{H}, \mathrm{NH}), 4.50\left(\mathrm{~m}, 1 \mathrm{H}, 1^{\prime \prime}-\mathrm{H}\right), 3.76\left(\mathrm{~s}, 3-\mathrm{H}, \mathrm{OCH}_{3}\right)$, $3.23\left(\mathrm{~m}, 2 \mathrm{H}, 2{ }^{\prime \prime}-\mathrm{H}\right) \mathrm{ppm} .{ }^{13} \mathrm{C} \mathrm{NMR}\left(\mathrm{CDCl}_{3}\right): \delta=178.2(\mathrm{C}-4)$, 172.2 (COOMe), 163.2 (C-2), 158.8 (C-8a), 151.4 (C-7), 135.4 (C$\left.1^{\prime \prime \prime}\right), 131.8\left(\mathrm{C}-1^{\prime}\right), 131.5\left(\mathrm{C}-4^{\prime}\right), 129.2\left(\mathrm{C}-3^{\prime \prime \prime}, \mathrm{C}-5^{\prime \prime \prime}\right), 129.0(\mathrm{C}-$ $\left.2^{\prime \prime \prime}, \mathrm{C}-6^{\prime \prime \prime}\right), 128.8$ (C-3', C-5'), 127.4 (C-5), 127.2 (C-4"' $), 126.2$ (C-2', C-6'), 114.9 (C-4a), 113.6 (C-6), 106.8 (C-3), 97.6 (C-8), 56.8 $\left(\mathrm{C}-1^{\prime \prime}\right), 52.6\left(\mathrm{OCH}_{3}\right), 38.1\left(\mathrm{C}-2^{\prime \prime}\right) \mathrm{ppm}$. IR $(\mathrm{KBr}): \tilde{v}=3396,3265$, 3152, 3065, 3028, 2948, 1726, 1624, 1593, 1538, 1507, 1448, 1436, $1370,1249,1191,1148,906,822,766,699 \mathrm{~cm}^{-1}$. MS: $\mathrm{m} / z=399$ $[\mathrm{M}]^{+*}, 340,308(100 \%), 248,221,165,91 . \mathrm{C}_{25} \mathrm{H}_{21} \mathrm{NO}_{4}$ (399.45): calcd. C 75.17, H 5.30, N 3.51; found C 75.21, H 5.33, N 3.54.

This product was also obtained as a by-product from the reaction of 6-bromoflavone (11) in 6\% yield.

7-\{[3-Methyl-1-(methoxycarbonyl)butyl|amino\}flavone (31c): Eluent: toluene/ethyl acetate, $2: 1$; yield $136 \mathrm{mg}(56 \%)$; m.p. $152-156{ }^{\circ} \mathrm{C} .{ }^{1} \mathrm{H}$ NMR $\left(\mathrm{CDCl}_{3}\right): \delta=8.01(\mathrm{~d}, J=8.6 \mathrm{~Hz}, 1 \mathrm{H}, 5-\mathrm{H}), 7.89(\mathrm{~m}, 2 \mathrm{H}$, $\left.2^{\prime}-\mathrm{H}, 6^{\prime}-\mathrm{H}\right), 7.50\left(\mathrm{~m}, 3 \mathrm{H}, 3^{\prime}-\mathrm{H}, 5^{\prime}-\mathrm{H}, 4^{\prime}-\mathrm{H}\right), 6.71(\mathrm{~s}, 1 \mathrm{H}, 3-\mathrm{H})$, $6.68(\mathrm{dd}, J=2.1,8.6 \mathrm{~Hz}, 1 \mathrm{H}, 6-\mathrm{H}), 6.56(\mathrm{~d}, J=2.1 \mathrm{~Hz}, 1 \mathrm{H}, 8-$ $\mathrm{H}), 4.80(\mathrm{~d}, J=8.6 \mathrm{~Hz}, 1 \mathrm{H}, \mathrm{NH}), 4.21\left(\mathrm{~m}, 1 \mathrm{H}, 1^{\prime \prime}-\mathrm{H}\right), 3.77$ (s, 3 $\left.\mathrm{H}, \mathrm{OCH}_{3}\right), 1.78\left(\mathrm{~m}, 3 \mathrm{H}, 2^{\prime \prime}-\mathrm{H}, 3^{\prime \prime}-\mathrm{H}\right), 1.02(\mathrm{~d}, J=6.5 \mathrm{~Hz}, 3 \mathrm{H}$, $\left.4^{\prime \prime}-\mathrm{H}\right), 0.97$ (d, $\left.J=6.1 \mathrm{~Hz}, 3 \mathrm{H}, 4{ }^{\prime \prime}-\mathrm{H}\right) \mathrm{ppm} .{ }^{13} \mathrm{C} \mathrm{NMR}\left(\mathrm{CDCl}_{3}\right)$ : $\delta=177.7$ (C-4), 173.9 (COOMe), 162.4 (C-2), 158.5 (C-8a), 151.8 (C-7), 132.0 (C-1'), 131.1 (C-4'), 128.9 (C-3', C-5'), 127.0 (C-5), 126.1 (C-2', C-6'), 115.5 (C-4a), 113.1 (C-6), 107.4 (C-3), 97.5 (C8), $54.6\left(\mathrm{OCH}_{3}\right), 52.4\left(\mathrm{C}-1^{\prime \prime}\right), 41.8\left(\mathrm{C}-2^{\prime \prime}\right), 24.9,22.7\left(\mathrm{C}-4^{\prime \prime}\right), 22.1$ $\left(\mathrm{C}-3^{\prime \prime}\right)$ ppm. IR (KBr): $\tilde{v}=3289,3153,3087,2953,1724,1620$, 1589, 1566, 1534, 1449, 1373, 1250, 1190, 1149, 1000, 9008, 824, 768, 686, $673 \mathrm{~cm}^{-1}$. MS: $m / z=365[\mathrm{M}]^{+\cdot}, 306(100 \%), 250,91$. $\mathrm{C}_{22} \mathrm{H}_{23} \mathrm{NO}_{4}$ (365.43): calcd. C 72.31, $\mathrm{H}$ 6.34, N 3.83; found $\mathrm{C}$ $72.35, \mathrm{H} 6.38, \mathrm{~N} 3.85$.

Supporting Information (see footnote on the first page of this article): Experimental procedures, physical and spectroscopic data $\left({ }^{1} \mathrm{H}\right.$ and ${ }^{13} \mathrm{C} N M R$, IR, and MS) for the products.

\section{Acknowledgments}

Financial support from the Hungarian Scientific Research Fund (OTKA) (grant number K75806) and from the New Hungary Development Plan, cofinanced by the European Social Fund and the European Regional Development Fund (project number TÁMOP4.2.2/B-10/1-2010-0024) is greatly appreciated.

[1] S. Khadem, R. J. Marles, Molecules 2012, 17, 191-206.

[2] a) R. G. Naik, S. L. Kattige, S. V. Bhat, B. Alreja, N. J. de Souza, R. H. Rupp, Tetrahedron 1988, 44, 2081-2086; b) S. Khadem, R. J. Marles, Molecules 2012, 17, 191-206.

[3] a) K. S. Kim, J. S. Sack, J. S. Tokarski, L. Qian, L. Leith, Y. F. Kelly, R. N. Misra, J. T. Hunt, S. D. Kimball, W. G. Hum- 
phreys, B. S. Wautlet, J. G. Mulheron, K. R. Webster, J. Med. Chem. 2000, 43, 4126-4134; b) H. Lu, D. J. Chang, B. Baratte, L. Meijer, U. Schulze-Gahmen, J. Med. Chem. 2005, 48, 737743; c) A. Montagnoli, B. Valsasina, V. Croci, M. Meninchinchieri, S. Rainoldi, V. Marchesi, M. Tibolla, P. Tenca, D. Brotherton, C. Albanese, V. Patton, R. Alzani, A. Ciavolella, F. Sola, A. Molinari, D. Volpi, N. Avanzi, F. Fiorentini, M. Cattoni, S. Healy, D. Ballinari, E. Pesenti, A. Isacchi, J. Moll, A. Bensimon, E. Vanotti, C. Santocanale, Nat. Chem. Biol. 2008, 4, 357-365; d) K. S. Kim, S. D. Kimball, R. N. Misra, D. B. Rawlins, J. T. Hunt, H. Y. Xiao, S. Lu, L. Qian, W. C. Han, W. Shan, T. Mitt, Z. W. Cai, M. A. Poss, H. Zhu, J. S. Sack, J. S. Tokarski, C. Y. Chang, N. Pavletich, A. Kamath, W. G. Humphreys, P. Marathe, I. Bursuker, K. A. Kellar, U. Roongta, R. Batorsky, J. G. Mulheron, D. Bol, C. R. Fairchilds, F. Y. Lee, K. R. Webster, J. Med. Chem. 2002, 45, 3905-3927; e) X. Lü, W. E. Burgan, M. A. Cerra, E. Y. Chuang, M.-H. Tsai, P. J. Tofilon, K. Camphausen, Mol. Cancer Ther. 2004, 3, 861-872; f) D. Rathkopf, M. A. Dickson, R. D. Carvajal, M. A. Shah, N. Wu, R. Lefkowitz, M. Gonen, L. M. Cane, H. J. Dials, J. L. Winkelmann, G. J. Bosi, G. K. Schwartz, Clin. Cancer Res. 2009, 15, 7405-7411; g) K. C. Bible, P. P. Peethambaram, A. L. Oberg, W. Maples, D. L. Groteluschen, M. Boente, J. K. Burton, L. C. Gomez-Dahl, J. D. Tibodeau, C. R. Isham, J. L. Maguire, V. Shridhar, A. K. Kukla, K. J. Voll, M. J. Mauer, A. D. Colevas, J. Wright, L. A. Doyle, C. Erlichman, Gynecol. Oncol. 2012, 127, 55-62.

[4] D. S. Bapat, K. Venkataraman, Proc. Indian Acad. Sci. 1955, $42 A, 336-341$

[5] a) M. Vijaya Lakshmi, N. V. Subba Rao, Curr. Sci. 1967, 36, 401-402; b) M. Vijaya Lakshmi, N. V. Subba Rao, Ind. J. Chem. 1972, 10, 34-37.

[6] H. Gao, J. Kawabata, Bioorg. Med. Chem. 2005, 13, 1661-1671.

[7] a) M. Cushman, D. Nagarathnam, D. L. Burg, R. L. Geahlen, J. Med. Chem. 1991, 34, 798-806; b) M. Cushman, H. Zhu, R. L. Geahlen, A. J. Kraker, J. Med. Chem. 1994, 37, 33533362.

[8] a) T. Akama, Y. Shida, T. Sugaya, H. Ishida, K. Gomi, M. Kasai, J. Med. Chem. 1996, 39, 3461-3469; b) Y. Shida, T. Sugaya, K. Gomi, M. Kasai, M. Moritomo, JPH 02256673, 1990; c) T. Akama, H. Ishida, Y. Shida, U. Kimura, K. Gomi, H. Saito, E. Fuse, S. Kobayashi, N. Yoda, M. Kasai, J. Med. Chem. 1997, 40, 1894-1900.

[9] D. A. Vasselin, A. D. Westwell, C. S. Matthews, J. Med. Chem. 2006, 49, 3973-3981.

[10] a) http://dctd.cancer.gov/FeaturedAgents/710464AminoflavoneProdrug.htm; b) K. M. Snader, B. R. Vishnuvajjala, T. Akama, WO 2002081462, 2002; c) A. M. Burger, B. Nguyen, WO 2010008731, 2010.

[11] a) M. P. Goetz, J. M. Reid, Y. Qi, A. Chen, R. M. McGovern, M. J. Kuffel, P. D. Scanlon, C. Erlichman, M. M. Ames, J. Clin. Oncol. 2011, 29, 2546 (Suppl.); b) P. P. Nandekar, A. B. Sangamwar, Expert Opin. Drug Discov. 2012, 7, 771-789.

[12] D. Dauzonne, B. Folléas, L. Martinez, G. G. Chabot, Eur. J. Med. Chem. 1997, 32, 71-82.

[13] a) T. Sawada, S. Hashimoto, S. Tohma, Y. Nishioka, T. Nagai, T. Sato, K. Ito, T. Inoue, M. Iwata, K. Yamamoto, Immunopharmacology 2000, 49, 285-294; b) T. Inaba, K. Tanaka, R. Takeno, H. Nagaki, C. Yoshida, S. Takano, Chem. Pharm. Bull. 2000, 48, 131-139; c) F. Du, L.-J. Lü, Q. Fu, M. Dai, J.-L. Teng, W. Fan, S.-L. Chen, P. Ye, N. Shen, X.-F. Huang, J. Qian, C.-D. Bao, Arthritis Res. Ther. 2008, 10, R136; d) K. Tanaka, T. Yamamoto, Y. Aikawa, K. Kizawa, K. Muramoto, H. Matsuno, A. Muragami, Rheumatology 2003, 42, 1365-1371.

[14] J. F. Geissler, J. L. Roesel, T. Meyer, U. P. Trinks, P. Traxler, N. B. Lydon, Cancer Res. 1992, 52, 4492-4498.

[15] M. K. Rastogi, K. Chaudhary, R. P. Kapoor, C. P. Garg, Indian J. Chem. B 1978, 16, 895-897.
[16] Y.-M. Cheng, S.-C. Pu, Y.-C. Yu, P. T. Chou, C.-H. Huang, C.T. Chen, T.-H. Li, W.-P. Hu, J. Phys. Chem. A 2005, 109, 11696-11706.

[17] N. N. Agrawal, P. A. Soni, Indian J. Chem. 2005, 44B, 26012603.

[18] F. Eiden, G. Patzelt, H. Buchborn, Arch. Pharm. 1989, 322, $589-592$.

[19] M. Lorenz, M. S. Kabir, J. M. Cook, Tetrahedron Lett. 2010, 51, 1095-1098.

[20] A. A. Raval, N. M. Shah, J. Org. Chem. 1956, 21, 1408-1411.

[21] L. Reichel, G. Hampel, Justus Liebigs Ann. Chem. 1966, 693, 216-224.

[22] G. Wurm, U. Geres, Arch. Pharm. 1978, 311, 177-183.

[23] L. Tang, S. Zhang, J. Yang, W. Gao, J. Cui, T. Zhuang, Molecules 2004, 9, 842-848.

[24] G. Wurm, U. Geres, Arch. Pharm. 1977, 310, 609-614.

[25] M. Cardenas, M. Marder, V. C. Blank, L. P. Roguin, Bioorg. Med. Chem. 2006, 14, 2966-2971.

[26] G. Wurm, U. Geres, Arch. Pharm. 1976, 309, 273-278.

[27] K. Görlitzer, Arch. Pharm. 1979, 312, 248-253.

[28] R. Larget, B. Lockhart, P. Renard, M. Largeron, Bioorg. Med. Chem. Lett. 2000, 10, 835-838.

[29] J. Quintin, C. Ruillier, S. Thoret, G. Lewin, Tetrahedron 2006, 62, 4038-4051.

[30] X. Zheng, W.-D. Meng, Y.-Y. Xu, J.-G. Cao, F.-L. Quing, Bioorg. Med. Chem. Lett. 2003, 13, 881-884.

[31] M. Ono, N. Yoshida, K. Ishibashi, M. Haratake, M. Arano, H. Mori, M. Nakayama, J. Med. Chem. 2005, 48, 7253-7260.

[32] J. Lee, T. Park, S. Jeong, K.-H. Kim, C. Hong, Bioorg. Med. Chem. Lett. 2007, 17, 1284-1287.

[33] C. Lecoutey, C. Fossey, L. Demuynck, F. Lefoulon, F. Fabis, S. Rault, Tetrahedron 2008, 64, 11243-11248.

[34] B. Bauvois, M.-L. Puiffe, J.-B. Bongui, S. Paillat, C. Monneret, D. Dauzonne, J. Med. Chem. 2003, 46, 3900-3913.

[35] D. Dauzonne, C. Grandjean, Synthesis 1992, 677-680.

[36] M. Michalska, Chem. Ind. 1966, 628-629.

[37] C. Paparao, K. V. Rao, V. Sundaramurthy, Synthesis 1981, 236 237.

[38] T. Patonay, K. Kónya, É. Juhász-Tóth, Chem. Soc. Rev. 2011, 40, 2797-2847.

[39] a) T. Patonay, R. Bognár, Gy. Litkei, Tetrahedron 1984, 40, 2555-2562; b) T. Patonay, J. Jekő, É. Rimán, Synth. Commun. 2002, 32, 2403-2415; c) N. De Meyer, A. Haemers, L. Mishra, H.-K. Pandey, L. A. C. Pieters, D. A. Vanden Bergen, A. J. Vlietinck, J. Med. Chem. 1991, 34, 736-746.

[40] T. Patonay, M. Rákosi, Gy. Litkei, R. Bognár, Liebigs Ann. Chem. 1979, 161-173.

[41] D. Dauzonne, L. Martinez, Tetrahedron Lett. 1995, 36, 18451848.

[42] D. T. Patoilo, A. M. S. Silva, J. A. S. Cavaleiro, Synlett 2010, 1381-1385.

[43] B. Zurowska, A. Erxleben, L. Glinka, M. Lecycka, E. Zyner, J. Ochoki, Inorg. Chim. Acta 2009, 362, 739-744.

[44] a) R. Bognár, C. O'Brien, E. M. Philbin, S. Ushioda, T. S. Wheeler, Chem. Ind. 1960, 1186; b) C. O'Brien, E. M. Philbin, S. Ushioda, T. S. Wheeler, Tetrahedron 1963, 19, 373-377.

[45] a) A. Takechi, H. Takikawa, H. Miyake, M. Sasaki, Chem. Lett. 2006, 35, 128-129; b) H. Miyake, S. Nishino, A. Nishimura, M. Sasaki, Chem. Lett. 2007, 36, 522-523.

[46] a) S. Guram, R. A. Rennels, S. L. Buchwald, Angew. Chem. Int. Ed. Engl. 1995, 34, 1348-1350; Angew. Chem. 1995, 107, 14561459; b) J. Louie, J. F. Hartwig, Tetrahedron Lett. 1995, 36, 3609-3612; c) M. Kienle, S. R. Dubbakka, K. Brade, P. Knochel, Eur. J. Org. Chem. 2007, 4166-4176, and the references cited therein; d) A. de Meijere, F. Diederich, Metal-Catalyzed Cross-Coupling Reactions, chapter 13, pp. 699-760, WileyVCH, Weinheim, Germany, 2004.

[47] B.-L. Deng, J. A. Lepoivre, G. Lemiere, Eur. J. Org. Chem. 1999, 2683-2688. 
[48] R. J. Fitzmaurice, Z. C. Etheridge, E. Jumel, D. N. Woolfson, S. Caddick, Chem. Commun. 2006, 4814 4816.

[49] T. Patonay, A. Vasas, A. Kiss-Szikszai, A. M. S. Silva, J. A. S. Cavaleiro, Aust. J. Chem. 2010, 63, 1582-1593.

[50] Y. Ju, R. S. Varma, Org. Lett. 2005, 7, 2409-2411.

[51] J. P. Wolfe, J. Ahman, J. P. Sadighi, R. A. Singer, S. L. Buchwald, Tetrahedron Lett. 1997, 38, 6367-6370.

[52] a) S. Lee, M. Jorgensen, J. F. Hartwig, Org. Lett. 2001, 3, 27292732; b) X. Huang, S. L. Buchwald, Org. Lett. 2001, 3, 34173419.

[53] M. L. Lee, K. H. Kang, Y. M. Lee, D. Kim, Y. S. Park, Bull. Korean Chem. Soc. 2008, 29, 1075-1078.

[54] Y. M. Ahn, L. Vogeti, C.-J. Liu, H. K. R. Santhapuram, J. M. White, V. Vasandani, L. A. Mitscher, G. H. Lushington, P. R.
Hanson, D. R. Powell, R. H. Himes, K. F. Roby, Q. Ye, G. I. Georg, Bioorg. Med. Chem. 2007, 15, 702-713.

[55] Among others: a) M. Schnürch, M. Spina, A. F. Kahn, M. D. Mihovilovic, P. Stanetty, Chem. Soc. Rev. 2007, 36, 1046-1057; b) N. de Souza, M. Vinicius, Curr. Org. Chem. 2007, 11, 637646; c) X.-F. Duan, Z.-B. Zhang, Heterocycles 2005, 65, 20052012; d) J. F. Bunnett, Acc. Chem. Res. 1972, 5, 139-147.

[56] Sz. Fekete, T. Patonay, A. M. S. Silva, J. A. S. Cavaleiro, ARKIVOC 2012, 5, 210-225.

[57] M. Brenner, W. Huber, Helv. Chim. Acta 1953, 36, 1109-1115. Received: August 19, 2014 Published Online: 


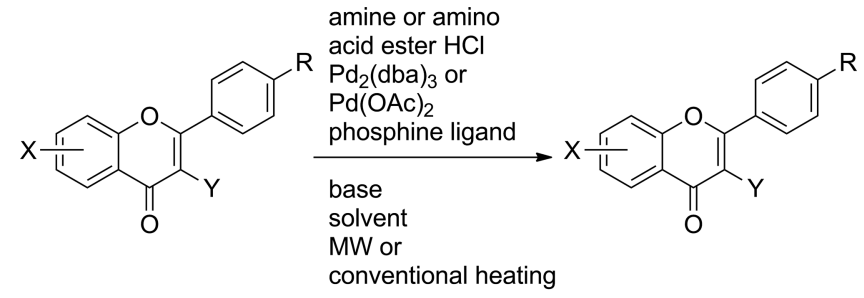

$\mathrm{X}=6 / 7 \mathrm{Cl} / \mathrm{Br}, \mathrm{Y}=\mathrm{H}, \mathrm{R}=\mathrm{H} / \mathrm{MeO}$ $\mathrm{X}=\mathrm{H}, \mathrm{Y}=\mathrm{Br}$

A new and efficient approach to (substituted) aminoflavones and hybrids of flavones and amino acids using Buchwald-
$X=6 / 7$ alkyl/aryl amino, amino acid moiety, $\mathrm{Y}=\mathrm{H}, \mathrm{R}=\mathrm{H} / \mathrm{MeO}$ $\mathrm{X}=\mathrm{H}, \mathrm{Y}=$ alkyl/aryl amino

Hartwig coupling was developed and optimised.
K. Kónya, D. Pajtás, A. Kiss-Szikszai,

T. Patonay* 1-13

Buchwald-Hartwig Reactions of Monohaloflavones

Keywords: Homogeneous catalysis / Crosscoupling / Amination / Palladium / Amino acids / Oxygen heterocycles 